Sandra Motikawa

\title{
Digestibilidade proteica de rações comerciais para o camarão rosa Farfantepenaeus paulensis Pérez-Farfante (1967): avaliação por métodos in vivo e in vitro
}

Dissertação apresentada ao Instituto Oceanográfico da Universidade de São Paulo, como parte dos requisitos para a obtenção do título de Mestre em Ciências, área de Oceanografia Biológica.

Orientador:

Prof. Dr. Daniel Eduardo Lavanholi de Lemos

São Paulo

2006 


\section{ÍNDICE}

Resumo

Abstract

1. Introdução

1.1. Situação atual da carcinicultura marinha brasileira 07

1.2. Ingredientes, nutrientes e processamento industrial das rações .......................................... 08

1.3. Avaliando a qualidade dos ingredientes das rações ............................................................ 09

2. Material e Métodos 11

2.1. Animais experimentais e infra-estrutura de cultivo 11

2.2. Substratos proteicos utilizados nas análises in vitro e caracterização quanto ao teor de proteína bruta, granulometria e energia 12

2.3. Determinação in vitro do grau de hidrólise enzimática da proteína alimentar 13

2.3.1. Enzimas experimentais e quantificação da atividade enzimática

2.3.2. Protocolo pH-stat com utilização de extrato enzimático de camarões e amostras de alimentos 14

2.4. Experimentos in vivo e in vitro 16

2.4.1. Digestibilidade de proteína em função da ontogênese 16

2.4.2. Digestibilidade in vitro de proteína em função do estado nutricional 17

2.4.3. Digestibilidade in vitro de proteína em função da fonte nutricional

2.4.4. Cultivo experimental com rações comerciais e correlação entre digestibilidade in

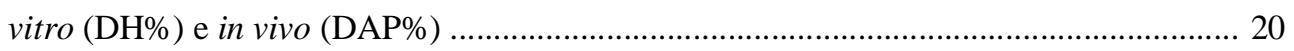

2.4.4.1. Etapa in vivo: seleção de organismos e fase de adaptação ......................... 20

2.4.4.2. Rotina experimental ...................................................................... 21

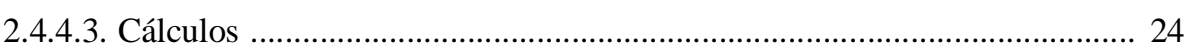

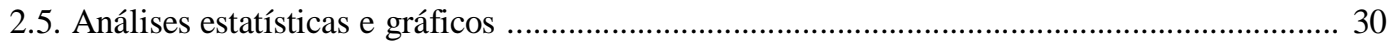

3. Resultados

3.1. Características das rações e substratos empregados ............................................................ 31

3.2. Digestibilidade de proteína em função da ontogênese ..................................................... 33

3.3. Digestibilidade de proteína em função do estado nutricional ................................................. 34

3.4. Digestibilidade de proteína em função da fonte nutricional ............................................... 35

3.5. Cultivo experimental com rações comerciais e correlação entre a digestibilidade in vitro (DH\%) e parâmetros in vivo

3.5.1. Características das rações quanto ao teor de umidade e taxa de lixiviação .............. 36

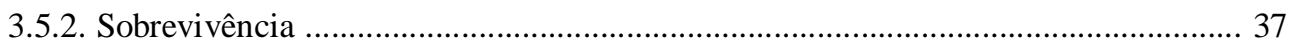

3.5.3. Taxa de ingestão alimentar diária ................................................................... 37

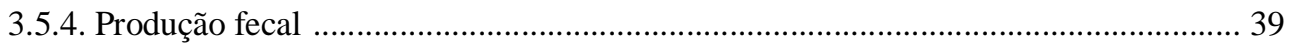

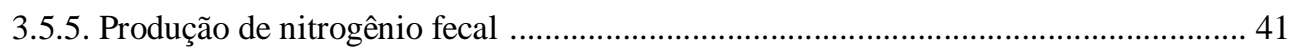

3.5.6. Digestibilidade aparente de matéria seca das rações ............................................... 43 
3.5.7. Digestibilidade aparente de proteína bruta (DAP\%) das rações

3.5.8. Correlação entre nitrogênio fecal e digestibilidade aparente de proteína bruta 45

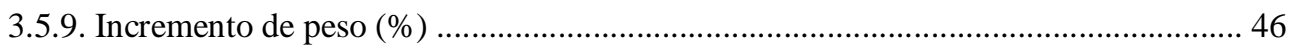

3.5.10. Correlação entre a digestibilidade proteica in vivo e in vitro ................................ 48

4. Discussão

4.1. Digestibilidade de proteína em função da ontogênese .............................................. 49

4.2. Digestibilidade de proteína em função do estado nutricional ....................................... 52

4.3. Digestibilidade de proteína em função da fonte nutricional ........................................ 52

4.4. Cultivo experimental com rações comerciais e correlação entre a digestibilidade in vivo $(\mathrm{DAP} \%)$ e in vitro $(\mathrm{DH} \%)$

4.4.1. Taxa de lixiviação das rações ............................................................... 55

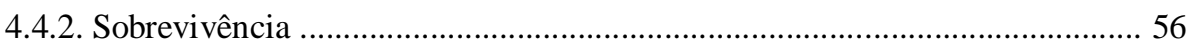

4.4.3. Taxa de consumo alimentar (ou de ingestão) .............................................. 56

4.4.4. Relação entre a taxa de consumo alimentar e a digestibilidade aparente de proteína 60

4.4.5. Digestibilidade aparente de matéria seca e digestibilidade de proteínas ....... 61 4.4.6. Relação entre incremento de peso e digestibilidades (aparente de proteínas e de matéria seca)

4.4.7. Correlação entre nitrogênio fecal e digestibilidade aparente de proteína bruta 62

4.4.8. Produção fecal e de nitrogênio fecal ....................................................... 63

4.4.9. Correlação da digestibilidade proteica in vivo e in vitro .............................. 64

4.4.10. Vantagens e precauções na aplicação do pH-stat ....................................... 67

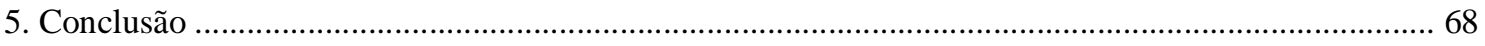

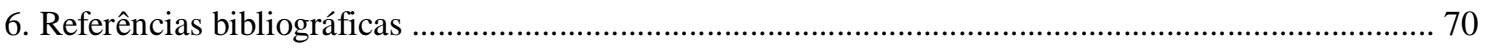

ÍNDICE DE FIGURAS E TABELAS

Fig. 1: Cronograma diário das rotinas de coleta das sobras de ração e fezes dos camarões-rosa Farfantepenaeus paulensis cultivados ao longo de 30 dias 22

Fig. 2: Grau de hidrólise, em porcentagem (DH\%) de proteínas da caseína e da farinha de peixe LT94, durante a ontogênese do camarão-rosa (Farfantepenaeus paulensis) .

Fig. 3: Grau de hidrólise, em porcentagem (DH\%) de proteínas da caseína em função do estado nutricional do camarão-rosa (Farfantepenaeus paulensis), alimentados ou submetidos a diferentes

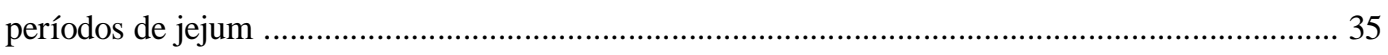

Fig. 4: Consumo diário de ração em peso úmido $(\mathrm{mg})$, por peso úmido de camarão $(\mathrm{g})$......................... 39

Fig. 5: Produção fecal diária (mg de peso seco) por peso úmido de camarão $(\mathrm{g})$................................. 41 
Fig. 6: Níveis de nitrogênio fecal $(\mu \mathrm{g} \mathrm{N})$ produzidos por peso úmido de camarão $(\mathrm{g})$......

Fig. 7: Correlação entre as médias de digestibilidade aparente (in vivo) de proteína bruta (\%) e de produção diária de nitrogênio fecal ( $\mu \mathrm{g} \mathrm{N}$ fecal) por peso úmido de camarão $(\mathrm{g})$

Fig. 8: Incremento de peso dos camarões, em porcentagem (\%)

Fig. 9: Correlação entre a digestibilidade aparente (in vivo) de proteína bruta e o grau de hidrólise in vitro das proteínas das rações com extratos de hepatopâncreas de $F$. paulensis

Tabela 1: Teores de proteína bruta presentes nos substratos empregados na hidrólise proteica in vitro e o conteúdo energético das rações A, B e C

Tabela 2: Frações granulométricas (\%) das rações moídas A, B e C, empregadas como substratos nas determinações in vitro de hidrólise de proteínas 32

Tabela 3: Grau de hidrólise (DH\%) proteica das rações A, B e C com a utilização de extratos enzimáticos de Farfantepenaeus paulensis cultivados com essas mesmas rações 36

Tabela 4: Características das rações A, B e C quanto às porcentagens de umidade contida nas formulações e de lixiviação

Tabela 5: Consumo diário das rações A, B e C, em pesos úmido e seco (g), por peso vivo (g) de camarãorosa Farfantepenaeus paulensis, expostos ao alimento durante $2 \mathrm{~h}$ por dia 38

Tabela 6: Produção diária peso-específica de fezes, em peso seco (mg fezes/g camarão) por animais alimentados com as rações $\mathrm{A}, \mathrm{B}$ e $\mathrm{C}$ 40

Tabela 7: Liberação diária de nitrogênio fecal por animais alimentados com as rações $\mathrm{A}, \mathrm{B}$ e C 42

Tabela 8: Digestibilidade aparente de matéria seca (DAMS\%) das rações A, B e C . 44

Tabela 9: Digestibilidade aparente de proteína (DAP\%) das rações A, B e C 44

Tabela 10: Incremento de peso (\%) de camarões cultivados com as rações A, B e C 46 


\section{Agradecimentos}

Aos meus pais, Kazuo e Tiyo, pelas palavras de apoio, incentivos, paciência e compreensão;

Aos funcionários, especialmente o pessoal técnico do Instituto Oceanográfico (campus SP): Zezé, Marta, Tomás, Manoel e Divaldo, pelo apoio metodológico, auxílio e companhia;

Aos funcionários da base do Instituto Oceanográfico “Clarimundo de Jesus” pelos auxílios e pela companhia durante o tempo em que permaneci em Ubatuba para a realização dos experimentos;

Aos amigos que me acompanham desde a faculdade e aos novos amigos que conheci no Instituto Oceanográfico, pela amizade e apoio;

Aos colegas de laboratório Raul e Leonardo, por terem cedido gentilmente as informações referentes ao conteúdo energético das amostras de rações;

Ao orientador Prof. Daniel e aos Profs. Phan e Vicente, pelo apoio metodológico e pela contribuição em minha formação profissional;

A agência CAPES, pela bolsa de pesquisa a mim concedida;

Meus agradecimentos a todos que contribuíram para que esse trabalho pudesse ser realizado. 


\section{Resumo}

O cultivo do camarão-rosa Farfantepenaeus paulensis pode ser viabilizado com alimentos de boa digestibilidade proteica, por melhorar o rendimento e reduzir a liberação de resíduos no meio ambiente. Um método in vitro que utiliza o titulador $\mathrm{pH}$ stat e enzimas digestivas da espécie estudada para avaliar a digestibilidade proteica, obteve resultados comparáveis aos alcançados pelo cultivo de salmonídeos e camarões (Litopenaeus vannamei). No presente trabalho de suporte nutricional ao camarão autóctone $F$. paulensis, analisou-se a performance de cultivo dessa espécie em relação a três rações comerciais, verificou-se a previsibilidade do método in vitro de digestibilidade proteica e complementou-se os conhecimentos metodólogicos dessa técnica. Nos resultados, a performance de cultivo diferiu conforme a ração empregada e houve correlação $\left(\mathrm{R}^{2}=0,55\right)$ entre os dados in vivo e in vitro de digestibilidade proteica para duas rações, sendo uma terceira ração excluída da análise devido às suas propriedades físicas, que possivelmente afetaram apenas a digestibilidade proteica in vivo. Os resultados obtidos com as enzimas empregadas no método in vitro diferiram pouco conforme a ontogênese, fonte alimentar e estado nutricional dos camarões. Os presentes resultados indicam que o método in vitro ainda não substitui o cultivo experimental, mas pode auxiliar na busca por alimentos adequados.

Palavras-chave: camarão-rosa; Farfantepenaeus paulensis; digestibilidade; método in vitro; proteína; rações; enzimas digestivas; cultivo experimental 


\begin{abstract}
Culture of pink shrimp Farfantepenaeus paulensis can be achieved by digestible feeds that may result in higher yields and reduced residual nutrient release into the environment. An in vitro method to assess protein digestibility in a $\mathrm{pH}$-stat reaction involving enzyme extracts of the target species was previously found to preview in vivo apparent protein digestibility in salmonids and shrimp Litopenaeus vannamei. The present survey explored culture performance of $F$. paulensis fed three commercial shrimp feeds and checked the potential of the $\mathrm{pH}$-stat method to preview apparent protein digestibility. Moreover, the suitability of using hepatopancreas enzyme extracts was assessed in terms of shrimp ontogenesis, nutritional status (fed/unfed) and diet history. Culture performance differed among feeds and a correlation $\left(\mathrm{R}^{2}=0.55\right)$ was found between in vivo and in vitro protein digestibility in two of the tested feeds. The remaining feed was excluded from analysis due to technical constraints that possibly affected apparent in vivo protein digestibility and culture performance. Shrimp hepatopancreas enzyme extracts employed for in vitro assays were not affected by ontogenesis, nutritional status and diet history. Though the in vitro method still cannot replace experimental rearing trials it can further assist in the search for adequate feedstuffs for shrimp rearing.
\end{abstract}

Key-words: pink-shrimp; Farfantepenaeus paulensis; digestibility; in vitro method; protein; feeds; digestive enzymes; experimental culture 


\section{Introdução}

\subsection{Situação atual da carcinicultura marinha brasileira}

Embora o Brasil tenha se destacado como um dos maiores produtores mundiais de camarões marinhos cultivados, com cerca de 75.904 toneladas despescadas e produtividade de 4,573 ton/ha em 2005 (Ibama, 2005), essa posição foi alcançada graças ao cultivo disseminado da espécie exótica Litopenaeus vannamei, o camarãobranco-do-Pacífico. Seu sucesso dependeu não só de características como rápido crescimento e rusticidade para cultivo, como também da disponibilidade de alimentos comerciais que atendessem seus requerimentos nutricionais (Lemos et al., 2000). O nível de conhecimento gerado em relação ao L. vannamei contrasta com a situação em que se encontram as espécies autóctones brasileiras. Apesar de várias delas terem grande importância comercial e serem consideradas potencialmente cultiváveis (Seiffert et al., 1997), seus volumes se limitam à pesca extrativa, sendo que algumas, como os camarões rosa Farfantepenaeus paulensis e F. brasiliensis, já demonstram sinais de comprometimento do estoque de adultos, devido à super exploração do recurso (Valentini et al., 1991; 2001). A espécie $F$. paulensis, encontrada nas regiões sul e sudeste do país (Iwai, 1978), vinha sendo cultivada principalmente nas décadas de 80 e 90. Porém, seu cultivo deteve-se principalmente por questões técnicas, incluindo a falta de um alimento comercial adequado para manter uma produção lucrativa e tornando as tentativas de cultivo uma prática de risco sujeita a baixos resultados (Lemos et al., 2000).

A posição alcançada pela carcinicultura brasileira é um exemplo do que os investimentos iniciais feitos em torno de uma espécie foram capazes de resultar: aprimoramento de técnicas de cultivo e manejo, desenvolvimento de tecnologias 
aplicadas no ciclo produtivo (laboratórios de larvicultura, engorda e processamento do camarão despescado) e a aquisição de conhecimentos sobre esse modo de produção. A mesma atitude poderia ser aplicada na criação de espécies naturais do território nacional, como Farfantepenaeus paulensis, cuja ampliação de informações técnicocientíficas permitiria orientar os produtores sobre como administrar a produção desses camarões, inclusive no campo nutricional. Apesar da inexistência atual de formulações espécie-específicas para $F$. paulensis, o mercado de rações ampliou-se muito nos últimos anos, com melhoras inclusive na tecnologia de produção (Waldige \& Caseiro, 2003).

\subsection{Ingredientes, nutrientes e processamento industrial das rações}

Estima-se que a ração represente cerca de 50 ou $60 \%$ do custo operacional de produção de camarões (Tan \& Dominy, 1997; Shiau, 1998), devendo apresentar uma boa qualidade para que o desempenho no cultivo seja compensador. Na composição de rações para crustáceos, a proteína é o nutriente mais caro e o principal fator limitante para o crescimento (Smith et al., 1985), sendo necessário em maiores proporções quando comparada a carboidratos e lipídeos. Há uma grande quantidade de matérias primas que podem ser utilizadas nas formulações, resultando em uma considerável variação na composição das rações (Cuzon et al., 1994). Entre os ingredientes utilizados, a farinha de peixe parece ser a alternativa de qualidade nutricional mais completa, embora a diminuição na oferta tenha elevado seus custos, limitando sua inclusão na formulação (Guzmán, 1996; Watanabe, 2002). Por isso, a utilização e procura por fontes alternativas de proteína, tais como rejeitos, subprodutos da pesca e pecuária e ingredientes de origem vegetal, vem aumentando, embora esses últimos possam ainda apresentar fatores antinutricionais (como inibidores enzimáticos e 
antivitamínicos) e deficiência de aminoácidos essenciais (Longas,1996).

Mesmo com idênticas formulações e fontes de ingredientes, não há garantia de que as dietas tenham o mesmo valor nutricional. Além da qualidade dos ingredientes poderem variar conforme a disponibilidade das fontes e da oferta de mercado (Nates \& Tacon, 2005), vários fatores desde o preparo, processamento, armazenamento dos ingredientes e do alimento já pronto, podem afetar a qualidade dos nutrientes (D’Abramo \& Castell, 1997) e o grau de digestão do produto.

\subsection{Avaliando a qualidade dos ingredientes das rações}

Diante dos quadros anteriormente apresentados, torna-se indispensável o controle de qualidade dos ingredientes presentes nas formulações. Neste quesito, a digestibilidade é um índice considerado adequado em estudos nutricionais (Smith et al., 1985; Akiyama et al., 1989; Sudaryono et al., 1996; Lee \& Lawrence, 1997) e está relacionada à capacidade dos nutrientes de um alimento serem absorvidos e direcionados ao crescimento e metabolismo dos animais cultivados (Lemos, 2003). Um alimento formulado pode oferecer uma excelente fonte de nutrientes e mesmo assim resultar em uma performance de cultivo inadequada, caso seus nutrientes não sejam digeridos e incorporados (Sudaryono et al., 1996). Um alimento ideal deve apresentar alta eficiência de utilização, evitando sobretudo, a poluição ambiental devido à sobrecarga desnecessária de nutrientes (Tacon, 2002). As excretas produzidas pelos componentes não digeríveis do alimento, assim como a parcela de ração não assimilada pelos animais, implica diretamente no volume de resíduos liberados pelos sistemas de cultivo, podendo provocar eutrofização, diminuição do oxigênio dissolvido na água e desequilíbrio na biota local, além da questão do desperdício de ração e o custo que isso significa aos produtores (Lemos, 2003). Estudos da digestibilidade de alimentos podem ser realizados através do cultivo de animais (método in vivo), que é um processo 
custoso, por exigir tempo (Dimes et al., 1994a) e mão-de-obra, ou por métodos in vitro, isto é, simulados em laboratório por meio de reações bioquímicas.

As proteínas são os nutrientes mais avaliados, devido à sua importância direta para o crescimento dos animais (Guillaume, 1997). Utilizando-se uma técnica in vitro de avaliação da digestibilidade proteica na qual se emprega um aparelho titulador ( $\mathrm{pH}$ stat), Dimes \& Haard (1994) e Dimes et al (1994a,b) desenvolveram protocolos para salmonídeos com o uso de enzimas digestivas retiradas das próprias espécies avaliadas e verificaram que os resultados, fornecidos em grau de hidrólise de proteínas (DH\%), correlacionavam em grande parte com os dados de cultivo desses animais, em relação ao crescimento e à digestibilidade in vivo de proteínas. A constatação incentivou os primeiros testes deste tipo com peneídeos, onde Ezquerra et al. (1997a; 1998) utilizaram enzimas do hepatopâncreas (glândula digestiva) de Litopenaeus vannamei e obtiveram resultados também favoráveis ao uso do método.

A importância desse fato, além da questão prática por se tratar de um teste in vitro com bons resultados, é a possibilidade de utilizar as enzimas provenientes das próprias espécies experimentais, mais representativas do que as enzimas comerciais disponíveis para estudos de digestibilidade (Dimes \& Haard, 1994; Dimes et al., 1994a,b; Ezquerra et al., 1997a, 1998; Lemos et al., 2004). Com base nos estudos de digestibilidade, pode-se investigar alimentos que sejam adequados à espécie $F$. paulensis, dentro de um padrão de qualidade ambiental.

O presente trabalho tem como objetivo principal contribuir com estudos nutricionais de suporte ao cultivo da espécie nativa Farfantepenaeus paulensis através dos seguintes tópicos: 
$\left.1^{\circ}\right)$ Análise da possível diferença entre as rações nos parâmetros avaliados (como digestibilidade in vivo de proteínas, crescimento e quantidade de material não digerido liberado na forma de fezes e nitrogênio fecal);

$2^{\circ}$ ) Verificação da capacidade do teste $\mathrm{pH}$-stat, na previsão da digestibilidade proteica em rações;

$3^{\circ}$ ) Análise de fatores fisiológicos dos camarões que possam alterar as respostas das enzimas no ensaio in vitro de digestibilidade de proteínas.

\section{Material e Métodos}

\subsection{Animais experimentais e infra-estrutura pré-experimental}

Os camarões-rosa utilizados no estudo foram obtidos durante a fase pós-larval $\left(\mathrm{PL}_{10-15}\right)$, junto à "Estação Marinha de Aquacultura" da Fundação Universidade Federal do Rio Grande (FURG) e transportados até a Base Norte do Instituto Oceanográfico da Universidade de São Paulo, localizada em Ubatuba. Atualmente há cinco gerações de camarões sendo cultivados em tanques circulares de 12.000 litros desde 2001. Técnicos realizam o manejo alimentar nos tanques de cultivo com fornecimento diário de ração comercial ad libitum, além da manutenção da qualidade da água, pela troca de $50 \%$ do volume de água marinha a cada 2 dias e limpeza periódica das paredes dos tanques. O suprimento de água marinha filtrada é efetuado por meio de bombas e a aeração nos tanques é gerada por um compressor radial elétrico. O cultivo é mantido sob fatores naturais de iluminação, temperatura e salinidade (34-35\%o). Os camarões utilizados no 
presente trabalho foram cultivados sob essas condições até o momento de coleta e/ou transferência para tanques ou aquários experimentais.

\subsection{Substratos proteicos utilizados nas análises in vitro e caracterização} quanto ao teor de proteína bruta, granulometria e energia

Tanto ingredientes (caseína e farinha de peixe LT94) como rações comerciais foram utilizados como substratos na determinação da digestibilidade in vitro de proteínas. Nessa análise, cada uma das rações empregadas foi previamente triturada com o auxílio de um moedor manual elétrico (Proctor Silex®). A seguir, as amostras moídas tiveram sua composição granulométrica determinada por meio de um jogo de peneiras graduadas (com malhas em diferentes tamanhos), empilhadas e acopladas a uma base de agitação (Bertel®). Como as rações empregadas devem apresentar padronização quanto ao conteúdo de proteína bruta, o teor de nitrogênio total de cada produto foi medido através de um auto-analisador C, N, H (Central Analítica IQ/USP). A seguir, a porcentagem de proteína bruta presente nas rações foi obtida multiplicando-se o teor de nitrogênio total por 6,25 (A.O.A.C, 1984). Não foi necessário determinar os teores proteicos dos substratos caseína e farinha de peixe LT94 pelo fato dessas informações serem previamente conhecidas.

Além do conteúdo proteico, também foi quantificado o teor de energia contida em cada ração através do método da combustão úmida (Lemos, 2000), que consiste em determinar a quantidade de oxigênio consumida na queima de uma amostra contendo matéria orgânica. Para a execução do procedimento, foram adicionados $\mathrm{KIO}_{3}(5 \%$ p/v) e ácido sulfúrico em cada amostra de 8-12mg de ração. A seguir, a solução foi colocada para ferver em um sistema de balões de vidro acoplados a um condensador e sistema de resfriamento. Após 1h de combustão, os balões foram resfriados e os conteúdos, 
diluídos com água destilada e levemente aquecidos, de modo a eliminar o iodo livre da solução. Para acelerar o processo, foi colocada uma fonte de borbulhamento de ar. Após realizar um novo resfriamento, foi adicionado KI (10\% p/v) nas soluções e as amostras foram tituladas com tiossulfato de sódio $0,1 \mathrm{~N}$. Posteriormente, o volume de oxigênio gasto na queima foi convertido por equivalentes energéticos para obtenção da quantidade de energia presente em cada amostra.

\subsection{Determinação in vitro do grau de hidrólise enzimática da proteína}

\section{alimentar}

Ao final de cada experimento realizado, os camarões-rosa foram sacrificados e seus hepatopâncreas, dissecados e armazenados em nitrogênio líquido $\left(-180^{\circ} \mathrm{C}\right)$ para posterior preparação dos extratos enzimáticos a serem utilizados na determinação da atividade enzimática (item 2.3.1) e na análise da digestibilidade in vitro de proteínas de rações e ingredientes (item 2.3.2).

\subsubsection{Enzimas experimentais e quantificação da atividade enzimática}

Os hepatopâncreas de $F$. paulensis previamente armazenados foram utilizados para a preparação dos extratos enzimáticos após os seguintes procedimentos: descongelamento das amostras mantidas em nitrogênio líquido, homogeneização (1:3 $\mathrm{p} / \mathrm{v})$ em água destilada e ajuste do $\mathrm{pH}(\sim 8,0)$ conforme leitura em um aparelho medidor

de pH (744 pHmeter, Metrohm®). Nos casos em que se utilizou hepatopâncreas individuais, o pH das amostras previamente homogeneizadas foi medido através de um eletrodo específico (Biotrode, Metrohm ${ }^{\circledR}$ ) para pequenos volumes de amostra. A seguir, as amostras de hepatopâncreas foram centrifugadas (centrífuga 5417R, Eppendorf®) sob refrigeração de $4^{\circ} \mathrm{C}$ a 10.000 x $g$ por 30 minutos e o sobrenadante formado pelo extrato enzimático foi separado cuidadosamente após descartes da fração lipídica 
superficial e do material depositado no fundo.

A atividade proteolítica total foi medida pela taxa de hidrólise do extrato enzimático em 1,0\% p/v do substrato de azocaseína em 50mM de tampão Tris em pH 7,5 (García-Carreño, 1992). Triplicatas de 10 $\mu 1$ do extrato enzimático foram misturadas com $0,5 \mathrm{ml}$ de solução de azocaseína a $25^{\circ} \mathrm{C}$. A reação enzimática para cada triplicata controle foi suspensa pela adição imediata de $0,5 \mathrm{ml}$ de $20 \%$ de ácido tricloroacético (TCA). O mesmo foi feito para cada triplicata experimental, após um período de incubação de 10 minutos. $\mathrm{O}$ material foi mantido sob refrigeração a $0^{\circ} \mathrm{C}$ por 10 minutos e centrifugado durante 5 minutos a $10.000 \times \mathrm{g}$. A leitura de absorbância do sobrenadante foi feita em espectrofotômetro (6300 Jenway®) na faixa de 440nm (Lemos et al., 2004). A atividade do extrato enzimático foi medida em unidades de absorbância $(\mathrm{U})=\Delta$ abs/min, sendo determinada pelo valor obtido pela diferença entre as médias das triplicatas experimentais e controles.

Para os experimentos de determinação de grau de hidrólise, foi padronizado o volume de extrato enzimático equivalente a $4 \mathrm{U}$ ( $\mathrm{U}=$ =unidades de atividade enzimática). A quantidade disponível de extrato enzimático correspondente àquela atividade enzimática padrão adotada foi o fator que possibilitou ou não a realização de mais de uma réplica para o ensaio do grau de hidrólise.

\subsubsection{Protocolo pH-stat com utilização de extrato enzimático de camarões}

\section{e amostras de alimentos}

Nos ensaios de determinação do grau de hidrólise in vitro, a quantidade de proteína bruta foi padronizada em $80 \mathrm{mg}$. Durante cerca de $1 \mathrm{~h}$, a amostra foi dissolvida em água destilada, auxiliada por um agitador magnético. Por esse período, o $\mathrm{pH}$ foi mantido em aproximadamente 8,0 pela adição de volumes de $\mathrm{NaOH}$ de diferentes 
normalidades. A quantidade de base adicionada foi considerada, de modo que o volume de solução protéica, mais o extrato enzimático (4U) e o volume adicional de água, caso necessário, apresentasse o volume final de $10 \mathrm{ml}$.

A reação pH-stat de hidrólise de proteínas mediada pelo titulador 718 STAT Titrino (Metrohm®) teve início pela adição do extrato enzimático (item 2.3.1) no recipiente de reação contendo a amostra solubilizada previamente preparada. Durante uma hora (tempo de reação padronizado), o aparelho monitora o $\mathrm{pH}$ no decorrer de uma reação enzimática e o mantém estável em uma faixa especificada $(\sim 8,0)$. Quando ocorre hidrólise das ligações peptídicas de uma proteína pela ação de enzimas digestivas, há diminuição no pH da reação (Adler-Nissen, 1986). O aparelho detecta esta alteração e corrige o pH pela adição de um pequeno volume $(\mu \mathrm{l})$ de base $(\mathrm{NaOH})$. No final da reação, a quantidade de base gasta é proporcional ao grau de hidrólise (DH\%) ou à digestibilidade in vitro da proteína de um alimento (Pedersen \& Egum, 1983).

Durante a reação, o gás nitrogênio é borbulhado no recipiente de hidrólise para evitar alteração do $\mathrm{pH}$ devido ao contato da solução com o $\mathrm{CO}_{2}$ presente no ar. A temperatura é mantida constante $\left(25 \pm 0,2{ }^{\circ} \mathrm{C}\right)$ através da imersão da cubeta de reação em uma jaqueta, onde a água recircula, alimentada por um banho térmico na temperatura desejada. $\mathrm{O}$ volume de $\mathrm{NaOH} 0,1 \mathrm{~N}$ gasto para manter o $\mathrm{pH}$ constante durante a reação é registrado automaticamente e o $\mathrm{DH} \%$ é calculado pelo aparelho por meio da seguinte fórmula (Adler-Nissen, 1986): 


$$
D H \%=\left(B * N_{b} * \alpha^{-1} *\left[P \% * 100^{-1} * 8^{-1}\right]\right) * 100
$$

onde: $\mathrm{B}=$ volume $(\mathrm{ml})$ de base $\mathrm{NaOH}$ gasta durante a reação;

$$
\begin{aligned}
& \mathrm{N}_{\mathrm{b}}=\text { normalidade do titulante (no caso, utilizou-se } 0,1 \mathrm{~N} \text { ); } \\
& \mathrm{P} \%=\text { conteúdo proteico na reação, expresso em } \% ; \\
& \alpha^{-1}=\text { fator de calibração (tabelado conforme a temperatura da reação. Nos }
\end{aligned}
$$

experimentos, foi utilizado $\alpha^{-1}=1,5$ para $\left.25^{\circ} \mathrm{C}\right)$.

Desse modo, quanto maior o valor de $\mathrm{DH} \%$, maior o número de ligações peptídicas hidrolisadas e, portanto, melhor a eficiência de encurtamento da proteína alimentar pelas enzimas do animal.

\subsection{Experimentos in vivo e in vitro}

Foram realizados quatro experimentos. Três deles destinaram-se a esclarecer se há influência de determinados fatores do cultivo sobre o desempenho das enzimas nos testes in vitro (mais precisamente, em relação a idade, alimento fornecido e estado de nutrição dos animais). O quarto experimento, principal e também de maiores proporções, foi proposto em busca de uma melhor compreensão sobre a alimentação e nutrição dos camarões-rosa cultivados, assim como para verificar a capacidade de previsão da digestibilidade de proteína pelo método $\mathrm{pH}$-stat.

\subsubsection{Digestibilidade de proteína em função da ontogênese}

Há indícios de que a digestibilidade de alimentos pode variar de acordo com a idade do camarão (Lee \& Lawrence, 1997). Se o método pH-stat puder servir como indicador da qualidade da proteína alimentar, é necessário verificar se as respostas in 
vitro podem variar em função da idade dos camarões de onde se obtêm os extratos enzimáticos. Com esse propósito, durante determinada fase da ontogênese de $F$. paulensis, foram coletados indivíduos de 1, 3, 8 e 12 meses de idade para amostragem de hepatopâncreas, provenientes dos estoques descritos no item 2.1. Os pesos aproximados apresentados pelos animais, conforme a idade, foram de: 0,2g (1 mês); 1,6g (3 meses); 5,4g (8 meses) e 11,7g (12 meses). Os camarões foram rapidamente sacrificados e os órgãos, removidos e armazenados imediatamente em nitrogênio líquido. O grau de hidrólise de proteínas (item 2.3.2) foi verificado com a utilização dos extratos enzimáticos (item 2.3.1) preparados a partir dos hepatopâncreas coletados. Como substratos para a reação (item 2.3.2), foram escolhidas a caseína (Technical from bovine milk, Sigma ${ }^{\circledR}$ ) e a farinha de peixe LT94 (Fiskeriforskning, Noruega), de qualidade padronizada, pelo objetivo de testar um ingrediente prático da fabricação de rações aqua.

\subsubsection{Digestibilidade in vitro de proteína em função do estado nutricional}

Como o protocolo de digestibilidade in vitro de proteínas com a utilização de enzimas digestivas das próprias espécies aqüícolas estudadas foi desenvolvido recentemente, a importância do estado nutricional dos camarões para a aplicação do método citado anteriormente ainda não havia sido investigada. Para avaliar este fator, 30 indivíduos de 12 meses de idade e peso úmido de 10-12g foram coletados e transferidos para aquários individuais de 15 litros. Durante 17 dias, o tratamento dos animais incluiu 3 alimentações diárias ad libitum com ração comercial para camarões (35\% de proteína bruta), troca diária de $50 \%$ do volume de água, retirada das fezes e dos restos alimentares. As condições ambientais do laboratório foram mantidas com ar condicionado para ajuste de temperatura $\left(25^{\circ} \mathrm{C}\right)$, fotoperíodo de $12 \mathrm{~h}$ claro : $12 \mathrm{~h}$ escuro e 
filtros do tipo cuno $(1 \mu \mathrm{m})$ para o tratamento da água marinha. Após este período, metade dos camarões foram mantidos com o regime de alimentação e o restante, submetidos ao jejum durante 1, 6, 24 ou 48h, com 3 réplicas por tratamento. Após cada período de jejum, os animais foram sacrificados e tiveram os hepatopâncreas extraídos e armazenados em nitrogênio líquido para posterior análise da digestibilidade in vitro de proteínas (item 2.3.2). Para cada amostra de hepatopâncreas de indivíduo mantido em jejum, uma amostra proveniente de indivíduo alimentado foi também coletada. O grau de hidrólise na reação pH-stat foi determinado utilizando caseína como substrato, preparada conforme o item 2.3.2.

\subsubsection{Digestibilidade in vitro de proteína em função da fonte nutricional}

Em um trabalho recente, foi mencionada a possibilidade do grau de hidrólise proteica in vitro diferir conforme a origem do hepatopâncreas utilizado, supostamente em decorrência do tratamento alimentar fornecido aos animais. Segundo Divakaran et al. (2004), o método in vitro seria recomendável apenas se fosse utilizado como substrato proteico o mesmo alimento ministrado no cultivo dos indivíduos (os quais, mais tarde, teriam seus hepatopâncreas dissecados para a preparação dos extratos enzimáticos).

Com o propósito de se testar esta afirmação, foram cultivados camarões com 3 rações comerciais diferentes. Era desejável o conhecimento prévio dos graus de hidrólise proteico de cada ração a ser empregada nos experimentos, de modo que fosse possível identificar rações com qualidades diferentes. Para isso, entre 4 rações comerciais disponíveis, foram escolhidas as 3 que apresentaram graus de hidrólise de proteína distintos entre si. Todas as rações testadas declaravam na embalagem conter $35 \%$ de proteína bruta, que é a porcentagem indicada para a fase de crescimento em que 
se encontravam os juvenis utilizados nos experimentos. A partir dos valores obtidos pela determinação do teor de nitrogênio total contido em cada amostra (item 2.2), foi calculada a quantidade de proteínas totais em cada ração e foram feitas a solubilização e a determinação do DH\% de proteína das amostras (item 2.3.2).

Cento e vinte camarões de 6 meses de idade cultivados conforme o item 2.1, foram selecionados pelo comprimento $(8,5$ a $9 \mathrm{~cm})$ e transferidos para 3 tanques de 1000 litros, com 40 indivíduos em cada um. Em cada tanque foi fornecida uma das 3 marcas de ração escolhidas (ração A, B ou C), a fim de adaptar os camarões ao alimento (fase de arraçoamento). O alimento foi fornecido duas vezes ao dia, durante 12 dias. $\mathrm{O}$ período foi adequado, pois a recomendação para o condicionamento de dietas é de, pelo menos, uma semana (D’Abramo \& Castell, 1997).

Dos 120 animais inicialmente estocados, metade foram escolhidos para participarem de um experimento de cultivo (item 2.4.4). Os camarões restantes (20 por tanque) continuaram sendo arraçoados por mais 2 meses. Após esse período, os animais foram sacrificados, os hepatopâncreas retirados e armazenados em tubos identificados conforme o tratamento alimentar recebido. A seguir, os tubos foram mantidos em nitrogênio líquido para posterior determinação da digestibilidade in vitro de proteínas. No procedimento do método in vitro (item 2.3.2), foram utilizados os extratos enzimáticos de cada um dos grupos de animais alimentados com as rações A, B e C. Como substrato proteico da reação de hidrólise, foram empregadas essas mesmas rações, uma por vez. O número máximo possível de combinações entre os tipos de extratos enzimáticos e substratos proteicos empregados foi de $3 \times 3=9$ possibilidades diferentes. Os extratos enzimáticos foram divididos em duas ou três alíquotas, onde o número de réplicas executadas dependeu do volume disponível de extrato enzimático, preparado conforme o item 2.3.1. 


\subsubsection{Cultivo experimental com rações comerciais e correlação entre}

\section{digestibilidade in vitro (DH\%) e in vivo (DAP\%)}

Este experimento consistiu em uma etapa para o cultivo, outra para a análise in vitro e a correlação entre ambas. A primeira etapa foi proposta para verificar a importância do tratamento alimentar empregado na performance de cultivo, mais especificamente em relação à digestibilidade aparente de proteínas. No entanto, outros fatores associados também foram analisados, como: sobrevivência, número de mudas, ingestão de ração, crescimento, digestibilidade de matéria seca e liberações de fezes e

nitrogênio fecal, além da possível interação entre esses parâmetros analisados. A segunda etapa teve como propósito determinar o grau de hidrólise proteica in vitro, com a utilização de extratos enzimáticos dos hepatopâncreas daqueles mesmos indivíduos experimentais cultivados. Em seguida, foi avaliado o potencial de previsão do método in vitro de digestibilidade de proteínas, em relação aos dados obtidos durante o cultivo dos camarões. Como substratos da reação in vitro foram empregadas as respectivas rações fornecidas para a alimentação dos animais.

\subsubsection{Etapa in vivo: seleção de organismos e fase de adaptação}

Após o período inicial de 12 dias de arraçoamento, conforme descrito no experimento anterior (2.4.3), foram selecionados 20 animais de cada tratamento alimentar (60 indivíduos no total) conforme o peso (5,0 a 5,9g e média de 5,45 \pm 0,26g). A seguir, os camarões foram transferidos para o laboratório. Cada indivíduo foi seco cuidadosamente com um pano macio, pesado em uma balança analítica (Sartorius®) de precisão de $0,0001 \mathrm{~g}$ e transferido para um aquário plástico transparente $(15 \mathrm{~L})$, com tampa para prevenir a possibilidade do animal saltar para fora. Durante a realização de testes prévios, houve mortalidade em cerca de metade dos camarões submetidos à 
pesagem, em decorrência do estresse muscular. Por isso, desta vez, no momento em que os animais foram soltos nos aquários, foi testado o aumento da intensidade de aeração como forma de tentar reanimar os animais que pudessem estar injuriados. Embora no início alguns indivíduos tenham ficado totalmente inertes e com o corpo virado de lado, após 30 minutos de exposição à forte aeração, os animais se recuperaram e não houve mortalidade nesse período.

Durante a fase de adaptação dos indivíduos ao ambiente de laboratório e aos aquários, a rotina de manejo consistiu na troca diária de água (cerca de 50\% do volume) e duas sessões de alimentação (total de $0,4 \mathrm{~g}$ de ração por dia por indivíduo), com os juvenis expostos ao alimento por 1h em cada sessão (das 8:00 às 9:00h e das 15:00 às 16:00h). Para cada indivíduo foi mantido o mesmo tratamento alimentar (ração A, B ou

C) da fase de arraçoamento. O período experimental teve início após 27 dias de adaptação à rotina laboratorial. O esquema de cultivo dos organismos consistiu em 60 aquários numerados (contendo animais), com 20 indivíduos por tratamento e 6 aquários controles (sem animais, para estimar as perdas de ração por lixiviação).

\subsubsection{Rotina experimental}

A rotina diária de cultivo dos camarões executada no período experimental encontra-se em detalhes na Fig. 1: 


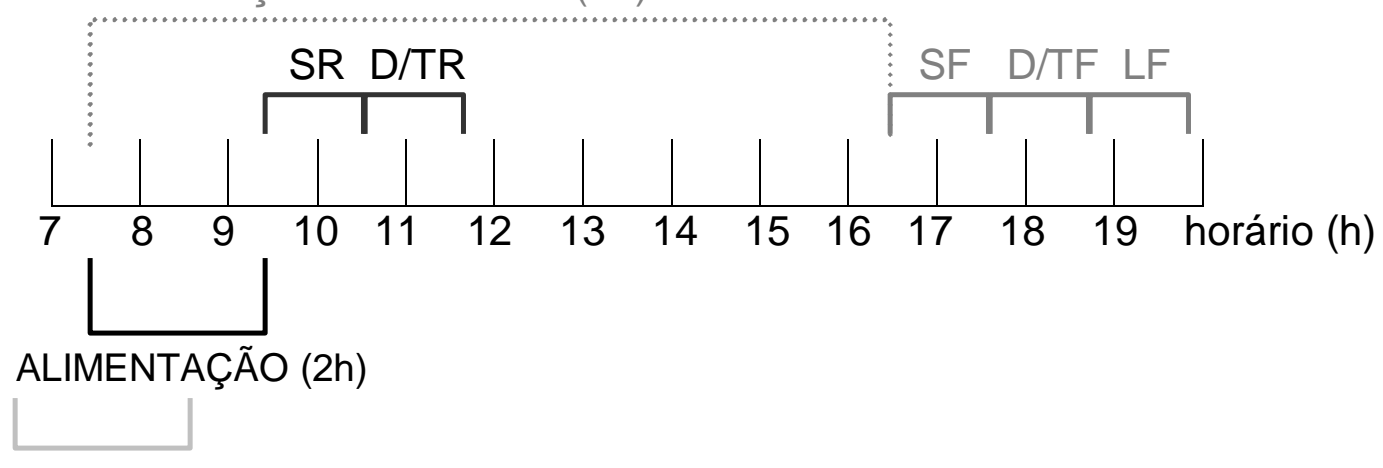

LIMPEZA E TROCA DE 50\% DO VOLUME DE ÁGUA (2h)

$$
\begin{aligned}
& \text { SR - SIFONAGEM DE RAÇÃO (1h) } \\
& \text { D/TR - DECANTAÇÃO } \\
& \text { TRANSFERÊNCIA DAS SOBRAS DE } \\
& \text { RAÇÃO PARA POTES }(1 \mathrm{~h})
\end{aligned}
$$

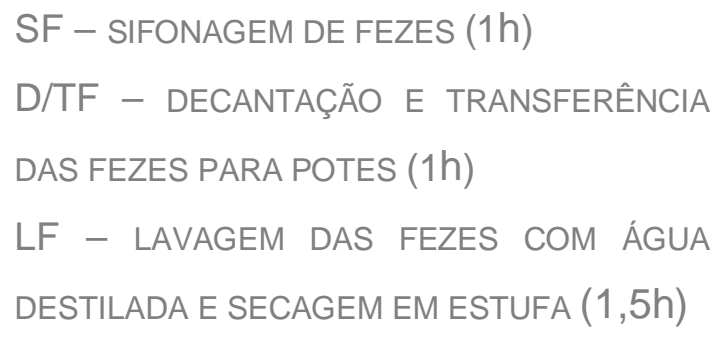

Fig. 1: Cronograma diário das rotinas de coleta de sobras de ração e fezes dos camarões-rosa Farfantepenaeus paulensis cultivados ao longo de 30 dias, a partir de um número amostral de 60 indivíduos, submetidos aos tratamentos alimentares A, B e C, respectivamente (20 animais por tratamento). As condições experimentais de temperatura e salinidade foram de $23^{\circ} \mathrm{C}\left( \pm 2^{\circ} \mathrm{C}\right)$ e $35 \%$.

Durante o período experimental foram mantidos os seguintes procedimentos:

- Fotoperíodo de $12 \mathrm{~h}$ claro : $12 \mathrm{~h}$ escuro;

- Temperatura de $23^{\circ} \mathrm{C}\left( \pm 2{ }^{\circ} \mathrm{C}\right)$;

- Fornecimento da mesma ração utilizada na fase de arraçoamento;

- Fornecimento de $2 \mathrm{~g}$ de ração por animal a cada 5 dias (aproximadamente 0,4g de ração ao dia por indivíduo) e disponibilidade de 2h diárias para alimentação;

- Troca de água dos aquários a cada 2 dias (50 a 60\% do volume) e limpeza prévia de detritos dos aquários em que eram realizadas as coletas do dia; 
- Coletas realizadas a cada $48 \mathrm{~h}$ devido ao revezamento dos aquários manejados: em cerca de metade (33) dos aquários eram feitas coletas em um dia e a outra metade (33), no dia seguinte. Ou seja, para cada indivíduo, houve coleta de materiais em dias alternados (dia sim, dia não), para que fosse possível a execução da tarefa, considerando-se a grande quantidade de aquários experimentais e o dispêndio de mão-de-obra;

- Obtenção das amostras individuais de sobras de ração, feitas em duas etapas: recolhimento do material depositado no fundo de cada aquário com a utilização de um sifão (tubo de vidro acoplado a uma mangueira) e transferência para um recipiente plástico ( 0,5L) para decantação do material depositado no fundo. A seguir, os sólidos foram transferidos com o auxílio de um tubo de vidro (de calibre fino) para outro recipiente plástico de menor volume $(\sim 20 \mathrm{ml})$, devidamente identificado segundo o número do animal. Esse procedimento foi necessário para diminuir o volume das amostras a serem estocadas no freezer;

- Coleta das fezes de cada indivíduo com o auxílio de um tubo de vidro e lavagem suave e ligeira com água destilada para retirar o sal marinho aderido. As fezes, por estarem envolvidas pela membrana peritrófica que é produzida pelo organismo do camarão, estão menos sujeitas à lixiviação do que a ração, sendo possível separá-las da água destilada com a ajuda de uma pipeta do tipo pasteur. Após o procedimento, o material foi guardado em potes (identificados com o número de cada animal) e armazenado no freezer;

- Descarte das sobras de alimento e fezes provenientes de animais que se encontravam sob estágio de muda, devido ao comportamento dos camarões de se alimentarem pouco quando se encontram nesse estado, conforme foi observado.

Após o término do período de cultivo experimental, os animais foram 
enxugados cuidadosamente, pesados e identificados quanto ao sexo. Os hepatopâncreas foram dissecados, dispostos individualmente em tubos identificados pelo número de cada animal e armazenados em nitrogênio líquido $\left(-180^{\circ} \mathrm{C}\right)$. Para as determinações individuais de ingestão de ração e produção fecal, foram descongelados os materiais armazenados no freezer (fezes previamente lavadas de modo suave e sobras de ração). As fezes correspondentes a cada indivíduo foram agrupadas por período de coleta. $\mathrm{O}$ mesmo foi feito em relação às sobras de ração. Por terem sido armazenadas ainda com água marinha, posteriormente ao agrupamento as sobras de ração foram lavadas suavemente com água destilada para retirada do sal e em seguida, filtradas por uma bomba de filtração a vácuo. Para a retenção do material, foram utilizados filtros descartáveis (código de referência AP4004700, filtro de microfibra de vidro sem resina, $47 \mathrm{~mm}$ de diâmetro, Millipore $\left.{ }^{\circledR}\right)$ pré-pesados. O agrupamento de materiais de cada indivíduo é recomendado para minimizar possíveis imprecisões na pesagem (Lee \& Lawrence, 1997), devido à quantidade relativamente pequena de alimento que é ingerida diariamente por cada animal e pela pequena quantidade de fezes resultantes (Smith \& Tabrett, 2004). Os materiais (fezes e as sobras de ração) foram secos em estufa $\left(60-65^{\circ} \mathrm{C}\right)$ até a obtenção de peso constante (peso seco). As fezes secas foram armazenadas em freezer $\left(-20^{\circ} \mathrm{C}\right)$ para posterior determinação do conteúdo de nitrogênio total (A.O.A.C, 1984).

\subsubsection{Cálculos}

Devido ao período relativamente longo de cultivo experimental (27 dias de aclimatação e 30 dias de coleta de materiais), foi necessário realizar o ajuste das estimativas individuais de incremento de peso, taxa de ingestão de ração e produções de fezes e nitrogênio fecal, de acordo com o peso adquirido por cada camarão durante cada período de coleta (total de 3 sequiências sucessivas, com 10 dias cada). Para evitar 
mortalidade ou estresse adicional aos animais, optou-se por pesá-los apenas duas vezes, antes do período de aclimatação e ao final do experimento, após terem sido sacrificados. Desse modo, o peso de cada juvenil no início de cada período de coleta teve que ser estimado através de equações lineares individuais (total de 60 equações do tipo $\mathrm{y}=a \mathrm{x}$ $+b$; onde $0,0022 \leq a \leq 0,0418$ e $4,9869 \leq b \leq 5,8670)$, calculadas com base nessas duas pesagens realizadas. Cada uma das equações (uma por indivíduo) permitiu estimar o peso apresentado por cada animal em função do tempo. Foi considerada a premissa de que a taxa de crescimento se apresentou constante durante todo o período experimental (57 dias no total). Os resultados dispostos nas tabelas estão expressos em médias e desvios padrões para cada um dos parâmetros avaliados, onde o número amostral (n) correspondeu ao total dos valores obtidos nas três coletas juntas (ou seja, cada indivíduo gerou um dado por coleta e portanto, 60 indivíduos geraram, no máximo, n = 180 dados nas três coletas). Já os resultados dispostos sob a forma de gráficos correspondem às médias apresentadas por cada indivíduo durante as três coletas. O número amostral total foi de $n=60$ dados, no máximo (cada animal gerou um dado a partir da média dos valores obtidos nas três coletas).

\section{Índice de lixiviação das rações}

O índice de lixiviação das rações nos aquários controle (sem animais) foi calculado para estimar as perdas ocorridas durante quase todo o processo de obtenção das sobras de ração (exceto pelo período de secagem em estufa), que incluem: o tempo em que o alimento permaneceu na água marinha com aeração ( $2 \mathrm{~h}$, o mesmo período conferido para a alimentação dos camarões); a retirada de ração do aquário por sifonagem; a lavagem suave com água destilada e a recuperação através do uso de filtros para a retenção dos sólidos. Este índice é importante, pois contabiliza a margem 
de erro que pode ocorrer durante estimativas de digestibilidade obtidas por métodos gravimétricos. Os cálculos foram obtidos a partir da seguinte fórmula:

Índice de lixiviação das rações $(\%)=100 *$ [Peso seco total de ração $(g)$ oferecida - Peso seco total de ração (g) recuperada no aquário controle] * [Peso seco total de ração $(g)$ oferecida] ${ }^{-1}$

\section{Cálculo da taxa de ingestão alimentar, com ajuste devido ao índice de}

\section{lixiviação}

Uma das formas de minimizar os agravantes proporcionados pela lixiviação foi estimando a quantidade de ração submersa disponível aos animais, ou seja, a parte que não sofreu dissolução após o contato com a água. Foram utilizados 2 tanques controle (isto é, sem animais) para cada uma das rações utilizadas, com sincronização do tempo em que o alimento permaneceu submerso nos aquários controles e experimentais (com animais). Considerando-se que a quantidade total de ração fornecida nos aquários experimentais e controles foi igual (cerca de $0,4 \mathrm{~g}$ diária de ração) e que todos os aquários foram submetidos aos mesmos procedimentos (tempo de imersão do alimento, lavagem de sal das sobras de ração, exposição à mesma temperatura e aeração), assumese que a quantidade de ração submersa que esteve disponível ao animal durante o período de alimentação foi equivalente ao peso médio de ração recuperada nos aquários controles (sem animais). As fórmulas descritas a seguir, aplicadas sobre os dados provenientes de cada indivíduo experimental, já estão com ajustes devido aos índices de lixiviação das rações.

A partir de um total de $2 \mathrm{~g}$ de ração úmida fornecida em 5 dias de coleta, foi calculada a taxa média de ingestão diária de matéria seca de ração (g) ao longo do 
período de cada coleta, através da fórmula:

Taxa média de ingestão diária de matéria seca (g de peso seco de ração/ dia) $=[$ Peso seco total da ração $(g)$ recuperada no aquário controle - Peso seco total das sobras de ração $(g)$ recuperadas no aquário experimental] $*\left(N^{o} \text { de dias de coleta }\right)^{-1}$;

onde a unidade da Taxa média de ingestão diária de matéria seca corresponde a: g de peso seco de ração $\cdot$ dia $^{-1}$

A fórmula anterior foi reescrita considerando o peso úmido do camarão no início do período de cada coleta (taxa de ingestão peso-específica):

Taxa média de ingestão diária de matéria seca, em peso específico $=($ Taxa média de ingestão alimentar, em peso seco)* (Peso do camarão no início do período de coleta $)^{-1}$

onde a unidade da Taxa média de ingestão diária de matéria seca, em peso específico corresponde a: $\mathrm{g}$ de peso seco de ração $\cdot \mathrm{g}$ de camarão ${ }^{-1} \cdot$ dia $^{-1}$

As fórmulas seguintes, das taxas de ingestão diária de ração, em peso úmido e peso úmido-específico ( $\mathrm{g}$ de ração úmida ingerida por g de camarão) foram obtidas a partir das fórmulas anteriores, porém com conversão de valores de peso seco, para peso úmido de ração, que consiste no peso "real" de ração conforme a embalagem dos produtos. A conversão foi realizada a partir da determinação da proporção de matéria seca presente nas rações (peso úmido). Esse procedimento foi efetuado através da pesagem de porções de $2 \mathrm{~g}$ de ração em peso úmido (recém tirado da embalagem), com 3 réplicas para cada marca de ração utilizada. Cada porção de ração foi seca em estufa a 
$65^{\circ} \mathrm{C}$ até a obtenção de peso constante. Assim, as taxas médias de ingestão diária de ração em peso úmido e peso úmido-específico foram obtidas de forma indireta:

Taxa média de ingestão diária de ração, em peso úmido = Taxa média de ingestão diária de ração, em peso seco * Proporção de matéria seca contida na porção inicial de ração ${ }^{-1}$

= Taxa média de ingestão diária de ração, em peso seco * (Peso seco da porção de ração pós secagem /Peso úmido da porção de ração pré-secagem) ${ }^{-1}$

Ao observar as unidades de medida correspondentes à formula anterior, verifica-se a existência de valores em g de ração em peso seco, tanto no numerador como no denominador. Portanto, o resultado é obtido na unidade desejada, que é a ingestão em g de ração úmida, por dia:

$=\left(\mathrm{g}\right.$ de ração em peso $\left.\sec \theta \cdot \mathrm{dia}^{-1}\right) *(\mathrm{~g}$ de ração em peso $\sec \theta) /(\mathrm{g}$ de ração em peso úmido $)=\mathrm{g}$ de ração em peso úmido $\cdot \mathrm{dia}^{-1}$

O mesmo foi feito em relação à taxa de ingestão diária de ração em peso úmido-específico:

Taxa média de ingestão diária de ração, em peso úmido-específico = Taxa média de ingestão diária de ração, em peso seco * Proporção de matéria seca contida na porção inicial de ração ${ }^{-1} *$ Peso do camarão no início do período de coleta $^{-1}$; 
onde a unidade da Taxa média de ingestão diária de ração, em peso úmidoespecífico equivale a: g de ração em peso úmido. $\mathrm{g}$ de camarão em peso úmido ${ }^{-1} \cdot \mathrm{dia}^{-1}$

\section{Cálculo da digestibilidade aparente de matéria seca (DAMS\%) das rações}

A porcentagem de matéria seca de ração assimilada pelos animais durante cada período de coleta foi calculada pela seguinte fórmula:

DAMS \% = $100 *$ (peso seco total de ração ingerida - peso seco total de fezes produzidas $) *(\text { peso seco total de ração ingerida })^{-1}$

\section{Cálculo da digestibilidade aparente de proteína (DAP\%) das rações}

Amostras das rações utilizadas e grande parte das amostras de fezes armazenadas ao longo do período experimental foram analisadas quanto ao conteúdo de nitrogênio total para o cálculo do teor proteico (A.O.A.C, 1984). A quantidade de proteína presente na ração ingerida e nas fezes liberadas e a digestibilidade aparente de proteína (DAP\%) em cada período de coleta foram então calculadas (modificado de Smith \& Tabrett, 2004):

Peso seco de proteína bruta fecal $(g)=$ peso seco total de fezes por período de coleta * Porcentagem de proteína bruta presente nas fezes (\%)

Peso seco de proteína ingerida $(g)=$ peso seco total de ração ingerida por período de coleta * Porcentagem de proteína bruta presente na ração (\%) 
DAP $(\%)=100 *[$ Peso seco de proteína bruta ingerida $(g)-$ Peso seco de proteína fecal $(g)] *[\text { Peso seco }(g) \text { de proteína bruta ingerida }]^{-1}$;

\section{Cálculo do incremento de peso dos camarões}

O incremento de peso (\%) apresentado por cada indivíduo (acréscimo de peso em relação ao início do período de coleta) foi calculado pela fórmula:

Incremento de peso $(\%)=100 *$ [peso inicial - peso final do camarão $(\mathrm{g})] *$ peso inicial (g) do camarão $o^{-1}$

\section{Determinação da digestibilidade in vitro da proteína de três marcas de}

\section{rações utilizando extratos enzimáticos de camarões cultivados}

Os hepatopâncreas dos camarões cultivados foram empregados na preparação dos extratos enzimáticos (item 2.3.1) e as rações, utilizadas como substratos, foram preparadas conforme o item (item 2.3.2). O extrato enzimático do hepatopâncreas de cada indivíduo foi utilizado para determinar o DH\% de proteínas da mesma ração fornecida durante o cultivo experimental. O número de réplicas possíveis de serem executadas para cada extrato individual variou de 1 a 4 , conforme a disponibilidade de volume de extrato enzimático. No total, foram realizados 88 ensaios.

\subsection{Análises estatísticas e gráficos}

Ao final do período de cultivo experimental, 6 indivíduos não apresentaram ganho de peso, entre os quais 3 pertenciam ao tratamento alimentar $\mathrm{B}, 2$ eram do tratamento A e 1 do C. Os dados provenientes desses indivíduos foram desconsiderados em todas análises realizadas, inclusive nas estatísticas. Os dados apresentados no presente trabalho foram analisados com o uso dos programas estatísticos SigmaStat 2.0 e Statistica 7.0. Nos casos em que os dados apresentaram um padrão de distribuição 
normal e de homogeneidade (dados paramétricos), foi aplicada a análise de variância de uma via (one-way ANOVA; $\mathrm{p}<0,05$ ), seguida do teste de Tukey para discriminação das diferenças. Quando algum desses dois pré-requesitos não foram atendidos (dados não paramétricos), foi utilizado o teste de Kruskal-Wallis $(\mathrm{p}<0,05)$ e depois o teste de Dunn para discriminação das diferenças. Nas análises de regressão foram calculados os coeficientes de determinação $\left(\mathrm{R}^{2}\right)$ e de correlação linear ( $\mathrm{R}$ de Pearson). Os gráficos foram construídos por meio do programa para planilhas de dados, Excel (Microsoft Office 97).

\section{Resultados}

\subsection{Características das rações e substratos empregados}

Os teores de proteína bruta (\%) dos substratos (rações e ingredientes) utilizados nos experimentos de digestibilidade in vitro de proteínas e o conteúdo de energia (\%) das rações A, B e C estão descritos na Tabela 1. Quanto ao teor de proteína bruta, as três rações apresentaram valores bastante semelhantes, em torno de 35\%. Já os ingredientes continham praticamente o dobro ou mais que o dobro da porcentagem de proteína bruta presente nas rações. A caseína, por ser uma proteína praticamente purificada, apresenta alto teor proteico, $90 \%$ e a farinha de peixe, $70 \%$. Em relação ao conteúdo energético das rações, os resultados obtidos para os três produtos foram similares, entre 15,6 a 16,6 $\mathrm{kJ} \cdot \mathrm{g}^{-1}$. 
Tabela 1: Teores de proteína bruta presentes nos substratos empregados na hidrólise proteica in vitro e o conteúdo energético das rações $A, B$ e $C$.

Substrato proteico

Proteína Bruta (\%)

Energia $\left(\mathrm{kJ}^{\mathrm{g}} \mathrm{g}^{-1}\right)$
A
35,2
15,6
B
35,7
16,6
$\mathrm{C}$
35,4
15,9
Caseína
90,0
Farinha de peixe LT94
70,0

As frações granulométricas resultantes do processo de moagem das rações (substratos) nos experimentos de determinação da digestibilidade in vitro de proteínas constam na Tabela 2. As três rações apresentaram distribuições granulométricas semelhantes, com maior quantidade de partículas de $250 \mu \mathrm{m}$ de tamanho e predominância de partículas na faixa de tamanho entre 355 a $180 \mu \mathrm{m}$, representadas por 82,3\%; 90,2\% e 85,2\% da fração granulométrica das rações A, B e C, respectivamente.

Tabela 2: Frações granulométricas (\%) das rações moídas A, B e C, empregadas como substratos nas determinações in vitro de hidrólise de proteínas

Granulometria $(\mu \mathrm{m})$

A

710

500

355

250

180

125
Proporção na amostra de ração (\%)

B

$\mathrm{C}$

2,3

0,4

1,4

8,9

2,4

1,6

32,6

16,9

12,4

36,5

39,4

48,8

13,2

33,9

24,0

6,5

6,9

11,6 


\subsection{Digestibilidade de proteína em função da ontogênese}

A análise estatística dos valores de $\mathrm{DH} \%$ de proteínas da farinha de peixe LT94 não indicou diferenças significativas ao longo do crescimento dos camarões (Fig. 2). Tanto o valor de $\mathrm{DH} \%$ como a amplitude desses valores foram relativamente baixos (DH\% de 2 a 3\%). Por outro lado, a caseína apresentou maior quantidade de proteínas hidrolisáveis, maior amplitude de valores (DH\% de 10 a 13\%) e conseqüentemente, maior refinamento para a percepção da variação desses valores, conforme o extrato enzimático testado.

Entre a amplitude de valores obtidos, foi possível verificar uma variação significativa $(\mathrm{p}<0,05)$ na capacidade de digestão das proteínas da caseína, apenas quando se comparou os valores de $\mathrm{DH} \%$ obtidos pelas enzimas de juvenis de 3 meses $(\mathrm{DH} \%=12,97 \pm 1,03 \%)$ em relação aos valores gerados pelas enzimas dos indivíduos de 8 meses de idade $(\mathrm{DH} \%=10,17 \pm 1,35)$. Animais mais novos, de 1 mês de idade, ou mais velhos, de 12 meses de idade, não apresentaram diferenças significativas nos valores de $\mathrm{DH} \%$ de proteínas $(11,01 \pm 1,19 \%$ e $11,84 \pm 0,85 \%$, respectivamente), em relação às demais idades. A farinha de peixe LT94 exibiu o mesmo padrão de oscilação nos valores de DH\% conforme a ontogênese (Fig.2), embora não significativos: 3,06 \pm $0,93 \% ; 3,20 \pm 0,96 \%$ e 2,34 $\pm 0,64 \%$, para animais de 1,3 e 8 meses de idade, respectivamente. 


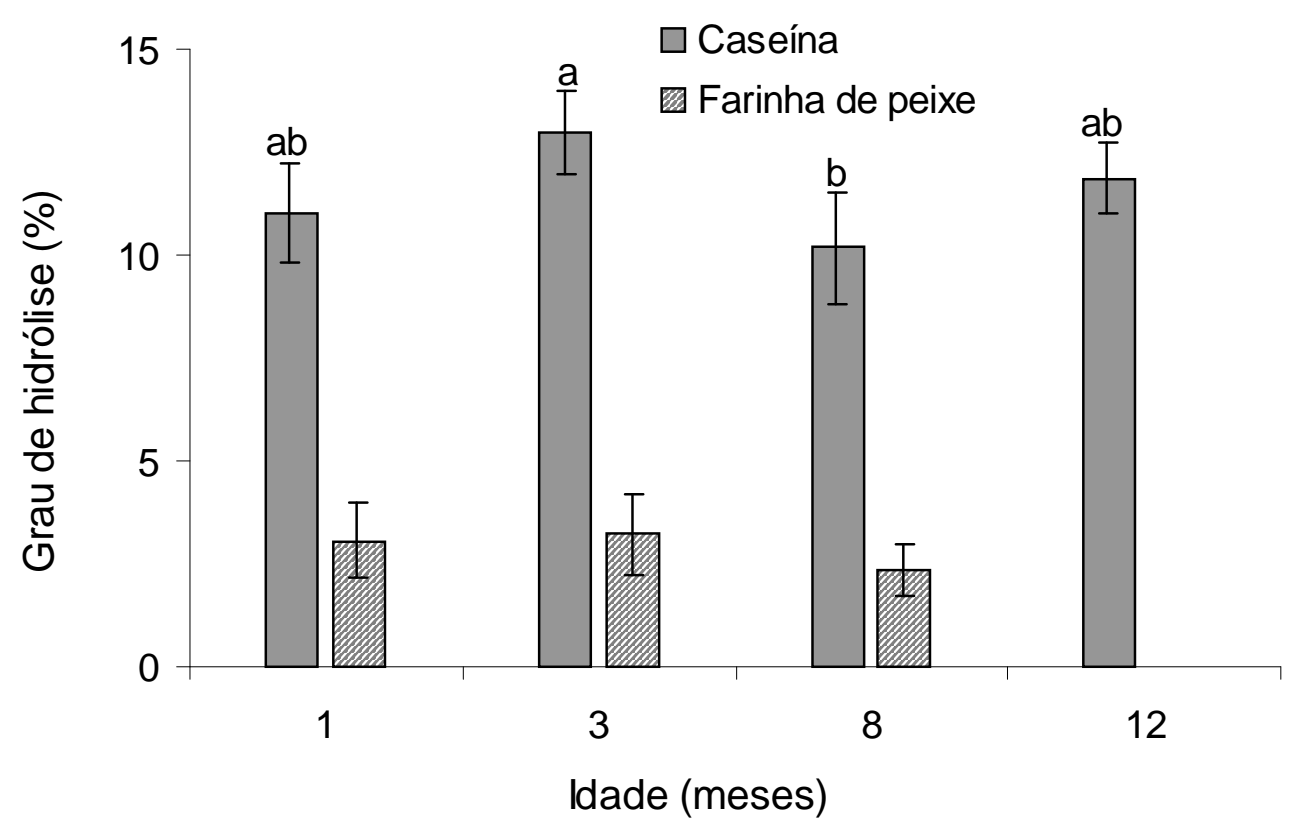

Fig. 2: Grau de hidrólise, em porcentagem (DH\%) de proteínas da caseína e da farinha de peixe LT94, durante a ontogênese do camarão-rosa (Farfantepenaeus paulensis). Os histogramas correspondem às médias e as barras, aos desvios padrões de $n=3$ a 15 réplicas para cada idade avaliada. As letras ( $a$ e b) acima das barras, quando distintas, correspondem a diferenças significativas $(p<0,05)$.

\subsection{Digestibilidade de proteína em função do estado nutricional}

Houve ligeira tendência de aumento nos valores médios de grau de hidrólise (DH\%) de proteínas da caseína com o uso de extratos enzimáticos de animais submetidos a períodos de jejum (Fig. 3). No entanto, em nenhum caso houve diferença significativa $(p>0,05)$ nos resultados decorrente do estado nutricional (de alimentação ou jejum) dos camarões. 


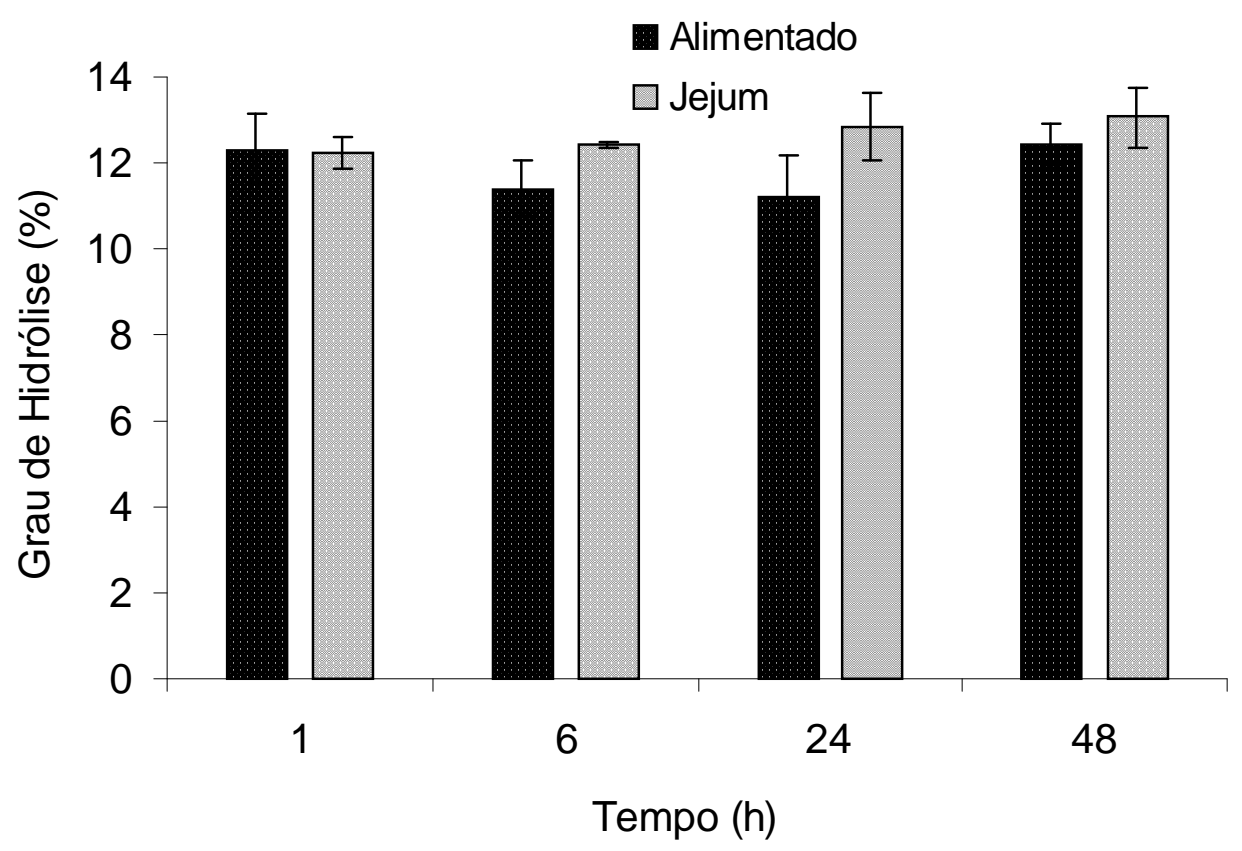

Fig. 3: Grau de hidrólise, em porcentagem ( $\mathrm{DH} \%$ ) de proteínas da caseína em função do estado nutricional do camarão-rosa Farfantepenaeus paulensis, alimentados ou submetidos a diferentes períodos de jejum. Os histogramas correspondem às médias e as barras, aos desvios padrões de $n=3$ réplicas para cada condição avaliada. A análise estatística não indicou diferença significativa entre os tratamentos avaliados $(p>0,05)$.

\subsection{Digestibilidade de proteína em função da fonte nutricional}

Não houve diferenças significativas $(\mathrm{p}>0,05)$ nos valores de $\mathrm{DH} \%$ proteico, segundo a análise de variância (ANOVA). Os dados foram comparados quanto à utilização de extratos enzimáticos provenientes de animais cultivados com diferentes tratamentos alimentares (vide linhas - Tabela 3).

Diferenças significativas $(\mathrm{p}<0,05)$ entre os valores de $\mathrm{DH} \%$ de proteína foram verificadas apenas em função da qualidade das rações A, B e C empregadas (vide colunas - Tabela 3), independentemente do extrato enzimático utilizado. 
Tabela 3: Grau de hidrólise (DH\%) proteica das rações A, B e C (substratos). Nos ensaios foram utilizados extratos enzimáticos de Farfantepenaeus paulensis cultivados com cada uma das rações anteriormente citadas. Letras em sobrescrito quando distintas, indicam diferenças significativas $(p<0,05)$ nos resultados, expressos em média, desvio padrão (entre parênteses) e número amostral (entre colchetes).

$\begin{array}{llll}\text { Extrato Enzimático* A } & \text { B }\end{array}$

\begin{tabular}{llll}
\hline$A^{\prime}$ & $2,66^{\mathrm{a}}(0,35)[4]$ & $1,23^{\mathrm{b}}(0,10)[4]$ & $1,38^{\mathrm{c}}(0,18)[4]$ \\
B $^{\prime}$ & $2,76^{\mathrm{a}}(0,50)[5]$ & $1,39^{\mathrm{b}}(0,54)[6]$ & $1,80^{\mathrm{c}}(0,23)[4]$ \\
C $^{\prime}$ & $2,13^{\mathrm{a}}(0,39)[5]$ & $1,07^{\mathrm{b}}(0,33)[5]$ & $1,54^{\mathrm{c}}(0,39)[7]$ \\
\hline
\end{tabular}

*Obtidos a partir de hepatopâncreas de camarões cultivados com as respectivas rações A, B e C

3.5. Cultivo experimental com rações comerciais e correlação entre a digestibilidade in vitro (DH\%) e parâmetros in vivo

\subsubsection{Características das rações quanto ao teor de umidade e taxa de}

\section{lixiviação}

Algumas das características das rações que possuem relação com o cálculo da ingestão alimentar são: a taxa de lixiviação e o teor de umidade (Tabela 4). Para as três rações analisadas, as taxas de lixiviação foram bastante similares (17,5 a 18\%). Já a porcentagem de umidade foi semelhante para as rações A e C, ambas com cerca de $9 \%$. A ração B apresentou teor de umidade de 6,6\%, que consiste em um valor aproximadamente $40 \%$ menor que as demais rações. 
Tabela 4: Características das rações $A, B$ e $C$ quanto às porcentagens de umidade e de lixiviação após procedimento de imersão em água marinha por $2 \mathrm{~h}\left(23 \pm 2^{\circ} \mathrm{C} ; 35 \%\right.$ ), breve lavagem com água destilada, filtração e secagem em estufa $\left(65^{\circ} \mathrm{C}\right)$. Os resultados foram expressos em média, desvio padrão (entre parênteses) e número amostral (entre colchetes).

\begin{tabular}{lccc}
\hline & A & B & C \\
\cline { 2 - 4 } Teor de umidade (\%); [3] & $9,0(0,3)$ & $6,6(0,1)$ & $9,2(0,8)$ \\
Lixiviação (\%); [6] & $17,5(1,7)$ & $18,0(3,6)$ & $17,8(3,3)$ \\
\hline
\end{tabular}

\subsubsection{Sobrevivência}

Durante todo período experimental não houve mortalidade associada ao tratamento alimentar oferecido aos camarões. No entanto, durante o $2^{\circ}$ período de coleta ocorreu a morte acidental de dois indivíduos pertencentes ao tratamento "B", por saltarem para fora dos aquários no momento da troca de água.

\subsubsection{Taxa de ingestão alimentar diária}

Foram analisados os dados de ingestão diária de ração (peso úmido e peso seco, em gramas) por peso vivo de camarão (g), em cada um dos 3 períodos de coleta (total de 30 dias). As diferenças encontradas $(\mathrm{p}<0,05)$ (Tabela 5) indicaram maior taxa de ingestão por unidade de peso $(\mathrm{g})$ de camarão para a ração $\mathrm{C}$, seguida pela ração $\mathrm{A}$ e por último, pela ração $\mathrm{B}$ (com os respectivos valores de 0,$020 ; 0,0182$ e 0,0146 , em peso úmido de ração e de 0,0182; 0,0165 e 0,0136, em peso seco de ração). Ao se comparar os valores de ingestão das rações A e B, em peso úmido-específico, é possível verificar que a diferença apresentada entre ambas é o dobro da encontrada entre A e C. Apesar das diferenças entre os resultados serem significativas, o fato anteriormente mencionado indica que as taxas de ingestão das rações $\mathrm{A}$ e $\mathrm{C}$, em peso úmido, são mais próximas entre si do que em relação à ração B. O mesmo se aplica às taxas de ingestão 
em peso seco de ração. Os resultados encontrados para as rações A e C estão mais próximos de $0,02 \mathrm{~g}$ (de peso seco de ração por $\mathrm{g}$ de camarão) do que a ração $\mathrm{B}$, que apresenta um valor mais próximo de $0,01 \mathrm{~g}$ de peso seco de ração por g de camarão.

Tabela 5: Ingestão diária das rações A, B e C, em pesos úmido e seco $(\mathrm{g})$, por peso úmido $(\mathrm{g})$ de camarão rosa Farfantepenaeus paulensis, expostos ao alimento durante $2 \mathrm{~h}$ por dia. Letras em sobrescrito quando distintas, indicam diferenças significativas $(p<0,05)$ nos resultados, expressos em média, desvio padrão (entre parênteses) e número amostral (entre colchetes). As condições experimentais de temperatura e salinidade foram de $23^{\circ} \mathrm{C}\left( \pm 2^{\circ} \mathrm{C}\right)$ e $35 \%$.

\begin{tabular}{lccc}
\hline & A & B & C \\
\hline Peso úmido & $0,0182^{\mathrm{d}}(0,0038)[54]$ & $0,0146^{\mathrm{e}}(0,0034)[51]$ & $0,0200^{\mathrm{f}}(0,0029)[53]$ \\
Peso seco & $0,0165^{\mathrm{d}}(0,0034)[54]$ & $0,0136^{\mathrm{e}}(0,0032)[51]$ & $0,0182^{\mathrm{f}}(0,0026)[53]$ \\
\hline
\end{tabular}

Na Fig. 4 é possível observar as tendências de consumo de ração (em g de peso úmido) conforme o tratamento alimentar. Para a construção do gráfico, foram considerados os dados de consumo médio de ração úmida por indivíduo, durante 30 dias. A freqüência de valores comparativamente elevados de consumo (superior a $21 \mathrm{mg}$ por g de camarão) é maior $(49,1 \%)$ entre os indivíduos que receberam a ração C. Por outro lado, a ração B apresentou a menor taxa de ingestão, onde a maior parte dos camarões $(58,8 \%)$ ingeriram menos que $15 \mathrm{mg}$ por grama corpórea. Por fim, a ração A foi a que teve consumo intermediário entre as duas rações, com maior frequência de valores entre 16 a $20 \mathrm{mg}(51,9 \%)$. 


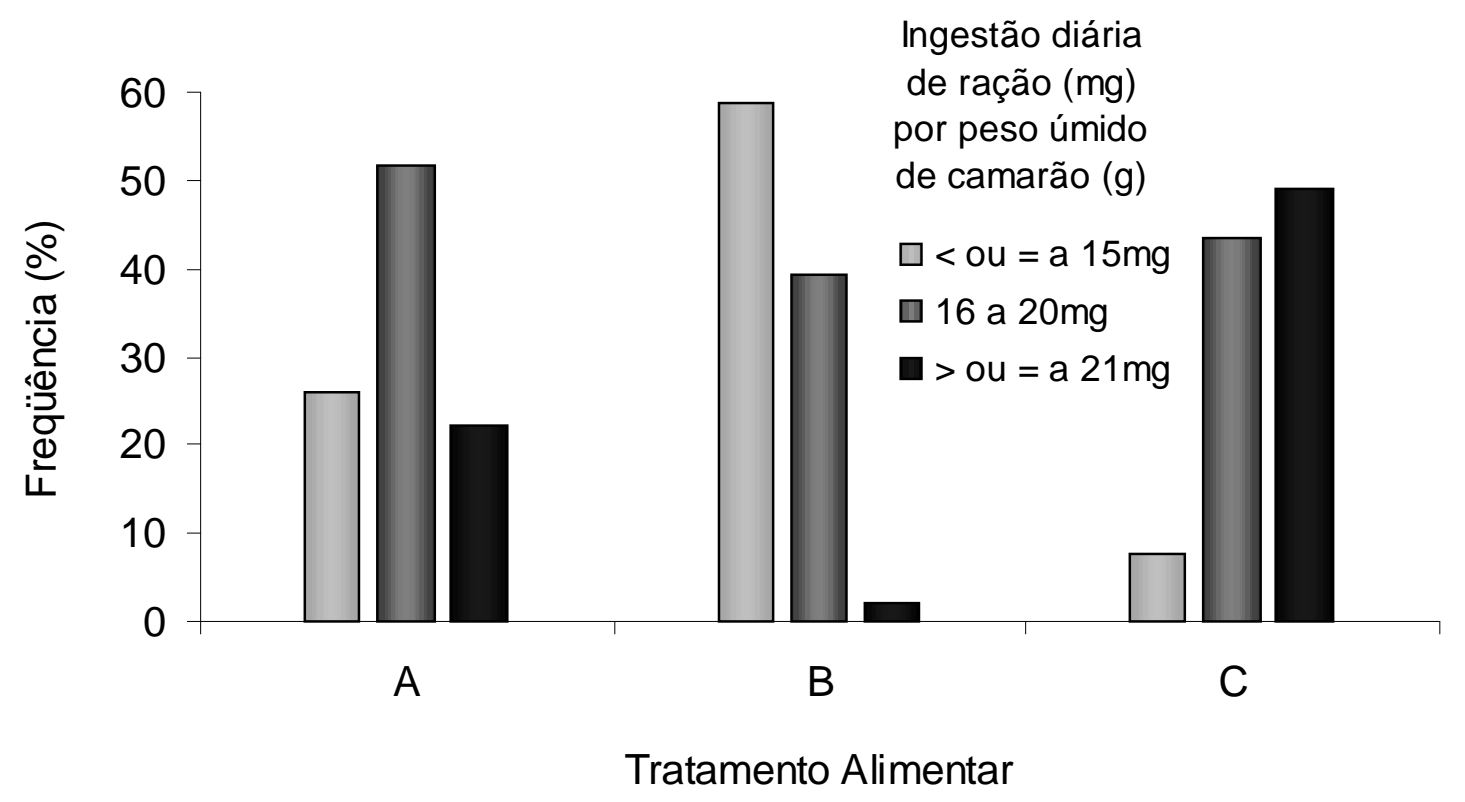

Fig. 4: Ingestão diária de ração em peso úmido $(\mathrm{mg})$, por peso úmido de camarão Farfantepenaeus paulensis $(\mathrm{g})$. Os histogramas correspondem à frequência (\%) de ração ingerida ao longo de 30 dias, a partir de um número amostral (n) de 18, 17 e 19 indivíduos, submetidos aos tratamentos alimentares $\mathrm{A}, \mathrm{B}$ e $\mathrm{C}$, respectivamente. As condições experimentais de temperatura e salinidade foram de $23^{\circ} \mathrm{C}\left( \pm 2^{\circ} \mathrm{C}\right)$ e $35 \%$.

\subsubsection{Produção fecal}

As diferenças entre as médias de produção fecal peso-específica (mg de peso seco de fezes produzidas/g de camarão) foram significativas $(\mathrm{p}<0,05)$ para os 3 tratamentos alimentares, com maior $(3,20)$, média $(2,17)$ e menor $(1,23)$ produção fecal para os camarões que receberam a ração C, A e B, respectivamente (Tabela 6). Através dos resultados é possível notar que as diferenças obtidas entre as três rações foram bastante acentuadas, aumentando em 65\% o valor (de $\mathrm{mg}$ de fezes produzidas/g de camarão) da ração B para a A, em 50\% da ração A para a C e em 147\%, ao se comparar os valores da ração $\mathrm{B}$ em relação à $\mathrm{C}$. Se forem considerados os valores de produção fecal em termos de peso absoluto, as diferenças encontradas entre os resultados adquirem proporção ainda maior. 
Tabela 6: Produção diária peso-específica de fezes de Farfantepenaeus paulensis, em peso seco (mg fezes/g camarão) por animais alimentados com as rações $A, B$ e $C$, ao longo de 30 dias. Letras em sobrescrito quando distintas, indicam diferenças significativas $(p<0,05)$ nos resultados, expressos em média, desvio padrão (entre parênteses) e número amostral (entre colchetes). As condições experimentais de temperatura e salinidade foram de $23^{\circ} \mathrm{C}\left( \pm 2^{\circ} \mathrm{C}\right)$ e $35 \%$.

\begin{tabular}{llll}
\hline & $\mathrm{A}$ & $\mathrm{B}$ & $\mathrm{C}$ \\
\cline { 2 - 4 } mg fezes/g camarão & $2,30(0,90) \mathrm{g}[36]$ & $1,39(0,62) \mathrm{h}[34]$ & $3,44(1,42) \mathrm{i}[34]$ \\
\hline
\end{tabular}

Ao analisar o desempenho das rações em relação à quantidade de fezes produzidas pelos camarões, verifica-se que $82 \%$ dos indivíduos alimentados com a ração B se enquadraram na menor classe de valores de produção fecal peso-específica, fato oposto ao apresentado pelos animais do tratamento alimentar $\mathrm{C}$, em que os maiores índices de produção fecal foram atribuídos a $47 \%$ dos indivíduos, representando a freqüência mais alta desse grupo (as demais freqüências foram de $35 \%$ e 18\%, correspondentes a camarões que produziram níveis médio e baixo de produção fecal, respectivamente) (Fig. 5). O tratamento A foi o que apresentou maior proporção de indivíduos $(50 \%)$ que atingiram níveis médios de produção fecal. 


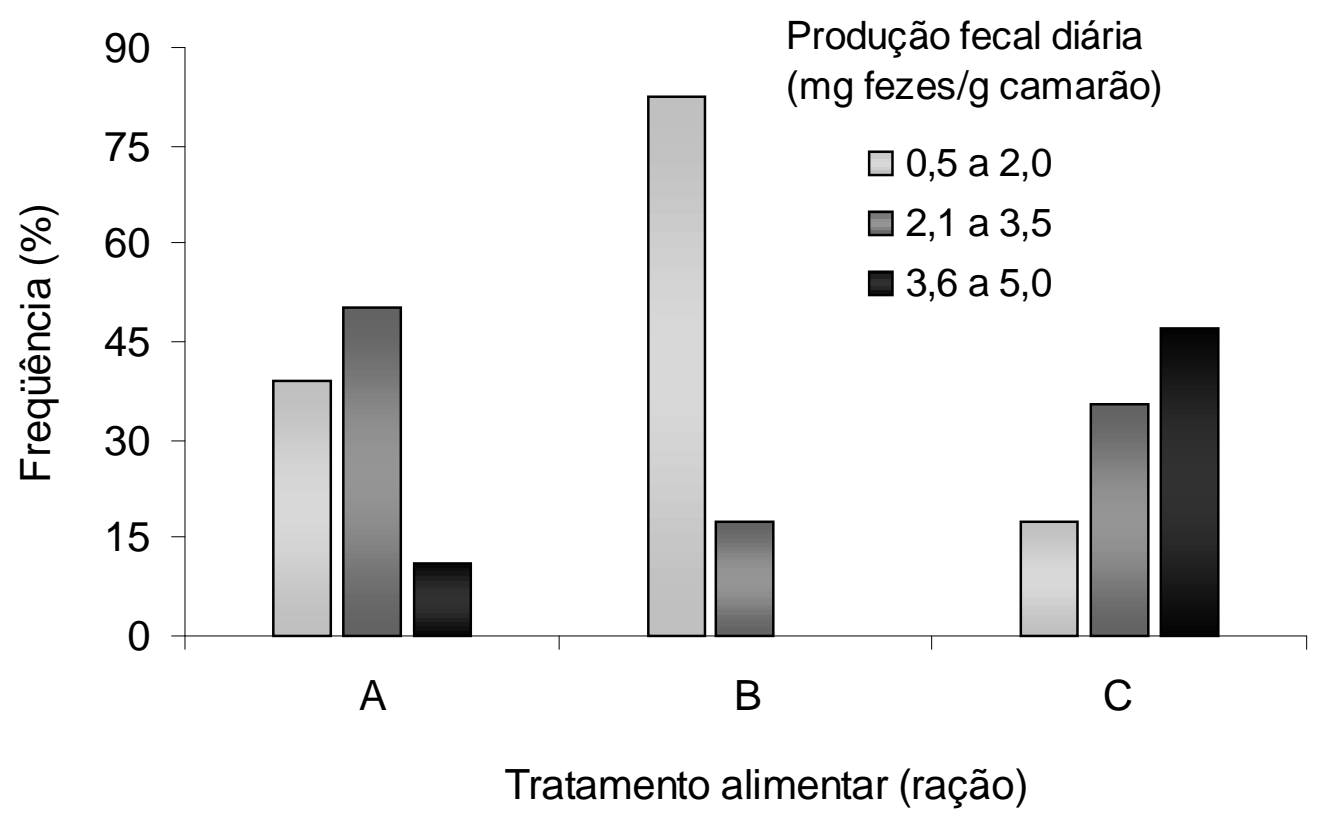

Fig. 5: Produção fecal diária (mg de peso seco) por peso úmido de camarão Farfantepenaeus paulensis $(\mathrm{g})$. Os histogramas correspondem às freqüências (\%) das quantidades de fezes produzidas ao longo de 30 dias, a partir de um número amostral (n) de 18, 17 e 19 indivíduos, submetidos aos tratamentos alimentares $\mathrm{A}, \mathrm{B}$ e $\mathrm{C}$, respectivamente. As condições experimentais de temperatura e salinidade foram de $23^{\circ} \mathrm{C}\left( \pm 2^{\circ} \mathrm{C}\right)$ e $35 \%$.

\subsubsection{Produção de nitrogênio fecal}

A análise da quantidade de nitrogênio fecal liberada diariamente (mg $\mathrm{N}$ fecal/g camarão) pelos camarões conforme o tratamento alimentar mostrou a ração $\mathrm{C}$ como associada aos maiores valores $(\mathrm{p}<0,05)$, com aproximadamente o dobro da quantidade de nitrogênio fecal liberada pelos animais do tratamento A e quase o triplo de B (Tabela 7). Não foi encontrada diferença significativa $(p>0,05)$ no desempenho dos tratamentos alimentares A e B. 
Tabela 7: Liberação diária de nitrogênio fecal por camarões Farfantepenaeus paulensis alimentados com as rações A, B e C. Letras em sobrescrito quando distintas, indicam diferenças significativas $(p<0,05)$ nos resultados, expressos em média, desvio padrão (entre parênteses) e número amostral (entre colchetes). As condições experimentais de temperatura e salinidade foram de $23^{\circ} \mathrm{C}\left( \pm 2^{\circ} \mathrm{C}\right)$ e $35 \%$.

\begin{tabular}{lccc}
\hline & $\mathrm{A}$ & $\mathrm{B}$ & $\mathrm{C}$ \\
\cline { 2 - 4 } mg N fecal/g camarão & $0,0446^{\mathrm{j}}(0,0180)[17]$ & $0,0304^{\mathrm{j}}(0,0167)[19]$ & $0,0887^{\mathrm{k}}(0,0292)[19]$
\end{tabular}

As tendências nos valores de liberação diária de nitrogênio $(\mathrm{N})$ fecal conforme os tratamentos alimentares encontram-se na Fig. 6. O padrão representado pelos histogramas é bastante semelhante entre as rações A e B, que apresentam alta freqüência (83\% e 92\%, respectivamente) de níveis baixos de $\mathrm{N}$ fecal liberado, baixa proporção de valores intermediários (17\% para a ração A e $8 \%$ para a B) e nenhuma ocorrência de liberação de níveis altos desse elemento. Por outro lado, o histograma representado pelo tratamento alimentar C mostra um padrão de distribuição na freqüência de valores bastante diferente dos observados anteriormente. A ração $\mathrm{C}$ alcançou a maior freqüência (54\%) de índices intermediários de liberação de $\mathrm{N}$ fecal, obteve a menor proporção de valores baixos de $\mathrm{N}$ fecal liberado e foi a única a atingir valores superiores a $100 \mu \mathrm{g}$ de nitrogênio por g de camarão, com uma freqüência de $38 \%$ dos casos apresentados. 


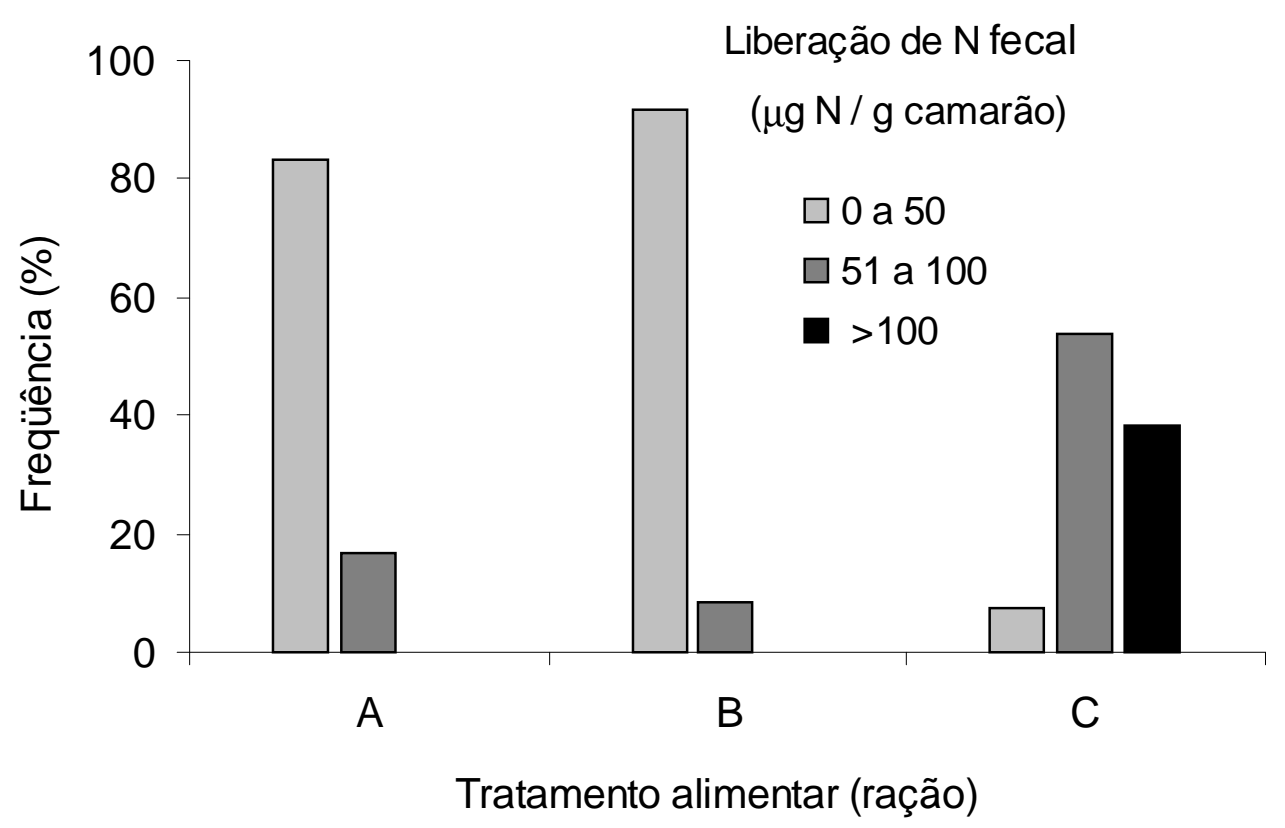

Fig. 6: Níveis de nitrogênio fecal $(\mu \mathrm{g} N)$ produzidos por peso úmido de Farfantepenaeus paulensis (g). Os histogramas correspondem às freqüências (\%) das quantidades de fezes produzidas ao longo de 30 dias, a partir de um número amostral (n) de 18, 17 e 19 indivíduos, submetidos aos tratamentos alimentares A, B e C, respectivamente. As condições experimentais de temperatura e salinidade foram de $23^{\circ} \mathrm{C}\left( \pm 2^{\circ} \mathrm{C}\right)$ e $35 \%$.

\subsubsection{Digestibilidade aparente de matéria seca das rações}

Houve diferenças significativas em relação aos valores de digestibilidade de matéria seca das rações (Tabela 8$)$, sendo as rações $\mathrm{A}$ e $\mathrm{B}$ superiores à $\mathrm{C}(\mathrm{p}<0,05)$. A menor diferença, de apenas 3\% (não significativa) foi encontrada entre as médias das rações A e B e a maior diferença, de 8,6\%, foi obtida entre as médias de B e C. 
Tabela 8: Digestibilidade aparente de matéria seca (DAMS\%) das rações A, B e C pelo camarão-rosa Farfantepenaeus paulensis. Letras em sobrescrito quando distintas, indicam diferenças significativas $(p<0,05)$ nos resultados, expressos em média, desvio padrão (entre parênteses) e número amostral (entre colchetes). As condições experimentais de temperatura e salinidade foram de $23^{\circ} \mathrm{C}\left( \pm 2^{\circ} \mathrm{C}\right)$ e $35 \%$.

\begin{tabular}{cccc}
\hline & A & B & C \\
\cline { 2 - 4 } DAMS (\%) & $86,63^{\mathrm{g}}(4,09)[36]$ & $89,55^{\mathrm{g}}(5,25)[33]$ & $80,94^{\mathrm{h}}(7,59)[34]$ \\
\hline
\end{tabular}

\subsubsection{Digestibilidade aparente de proteína bruta (DAP\%) das rações}

As médias de digestibilidade aparente de proteína bruta apresentaram diferenças significativas $(\mathrm{p}<0,05)$ apenas em relação à ração $\mathrm{C}$, que possui menor $\mathrm{DAP} \%$ em relação às rações A e B (Tabela 9). As diferenças encontradas entre as médias de DAP\% foram comparativamente menores do que no caso da digestibilidade de matéria seca. A menor diferença, de apenas $0,73 \%$ (não significativa), ocorreu entre as médias de A e B e a maior, foi entre as médias de B e C, com uma diferença de $5,05 \%$.

Tabela 9: Digestibilidade aparente de proteína (DAP\%) das rações A, B e C pelo camarão-rosa Farfantepenaeus paulensis. Letras em sobrescrito quando distintas, indicam diferenças significativas $(p<0,05)$ nos resultados, expressos em média, desvio padrão (entre parênteses) e número amostral (entre colchetes). As condições experimentais de temperatura e salinidade foram de $23^{\circ} \mathrm{C}\left( \pm 2^{\circ} \mathrm{C}\right)$ e $35 \%$.

\begin{tabular}{|c|c|c|c|}
\hline & A & B & $\mathrm{C}$ \\
\hline DAP (\%) & $95,51^{\mathrm{i}}(1,53)[16]$ & $96,24^{\mathrm{i}}(1,85)[19]$ & $91,19^{\mathrm{j}}(2,97)[19]$ \\
\hline
\end{tabular}




\subsubsection{Correlação entre nitrogênio fecal e digestibilidade aparente de}

\section{proteína bruta}

Segundo as fórmulas para o cálculo de digestibilidade, a proporção de nutriente assimilado a partir da ingestão de certa quantidade de alimento possui relação oposta ao volume de nutriente presente nas fezes. Com base nesse conceito foi construído o gráfico para verificar a correlação entre a digestibilidade aparente de proteína bruta e o nitrogênio fecal (ou de proteína fecal, se multiplicado por 6,25) (Fig. 7). Foram obtidas correlações altas e significativas $(p<0,05), \operatorname{com}^{2}=0,93$ e $R$ de Pearson $=-0,96$.

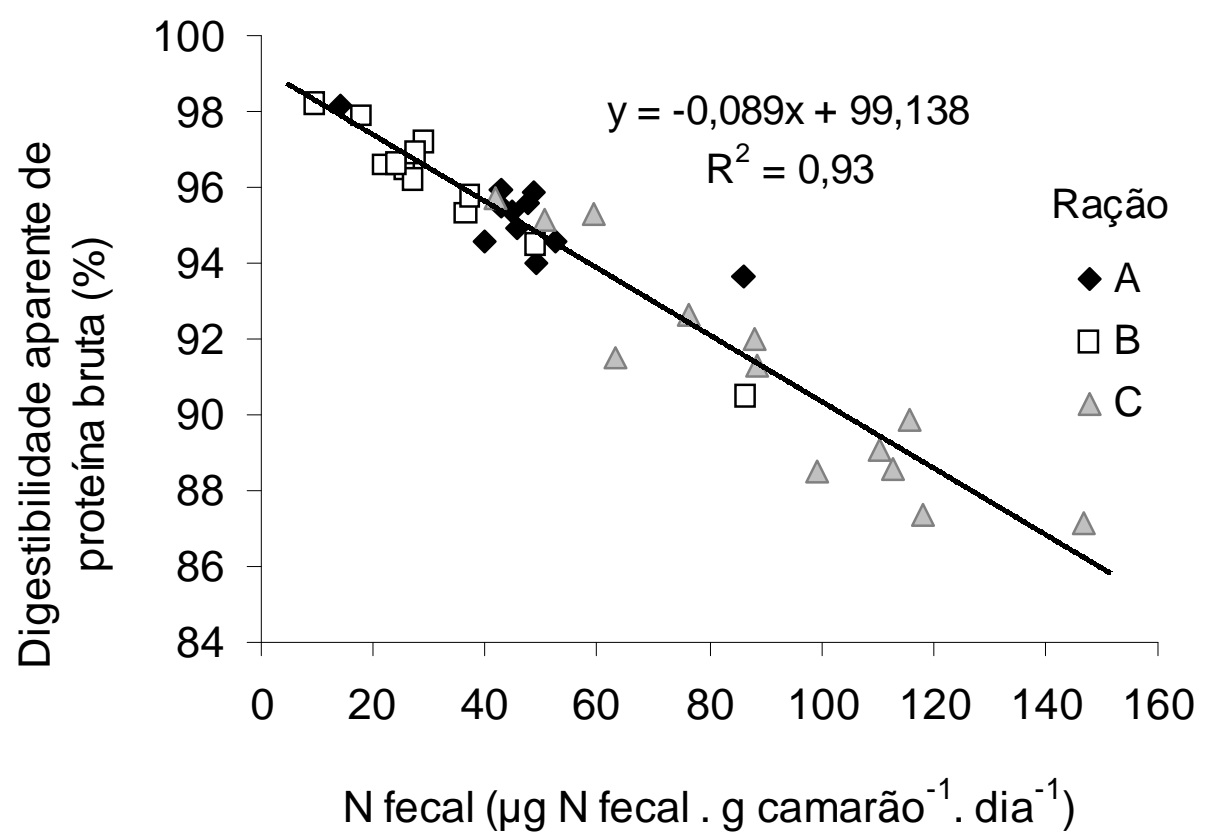

Fig. 7: Correlação entre as médias de digestibilidade aparente (in vivo) de proteína bruta (\%) e de produção diária de nitrogênio fecal ( $\mu \mathrm{g} N$ fecal) por peso úmido $(\mathrm{g})$ de camarão Farfantepenaeus paulensis ao longo de 30 dias, a partir do número amostral (n) de 12, 12 e 13 indivíduos, submetidos aos tratamentos alimentares A, B e C, respectivamente. As condições experimentais de temperatura e salinidade foram de $23^{\circ} \mathrm{C}\left( \pm 2^{\circ} \mathrm{C}\right)$ e $35 \%$. 


\subsubsection{Incremento de peso $(\%)$}

O incremento de peso dos camarões, em porcentagem, foi obtido em relação ao peso estimado de cada indivíduo no início do período experimental (duração de 30 dias). Não se detectou influência de fatores como sexo ou número de mudas sobre o incremento de peso dos animais. Foram encontradas diferenças significativas $(p<0,05)$ no crescimento de camarões alimentados com as rações $\mathrm{C}$ e $\mathrm{B}$, que apresentaram maior $(8,5 \%)$ e menor $(5,7 \%)$, incremento de peso, respectivamente (Tabela 10$)$. A ração A foi responsável por um incremento de peso intermediário $(6,7 \%)$, embora sem diferenças significativas em relação às duas outras rações $(p>0,05)$.

Tabela 10: Incremento de peso (\%) do camarão-rosa Farfantepenaeus paulensis cultivado com as rações $A, B$ e $C$. Letras em sobrescrito quando distintas, indicam diferenças significativas ( $p$ $<0,05)$ nos resultados, expressos em média, desvio padrão (entre parênteses) e número amostral (entre colchetes). As condições experimentais de temperatura e salinidade foram de $23^{\circ} \mathrm{C}\left( \pm 2^{\circ} \mathrm{C}\right)$ e $35 \%$.

\begin{tabular}{lccc}
\hline & $\mathrm{A}$ & $\mathrm{B}$ & $\mathrm{C}$ \\
\cline { 2 - 4 } Incremento de peso $(\%)$ & $6,7^{\mathrm{i}, \mathrm{y}}(4,3) ;[18]$ & $5,7^{\mathrm{i}}(2,9) ;[17]$ & $8,5^{\mathrm{y}}(2,7) ;[17]$ \\
\hline
\end{tabular}

Observando-se no gráfico as freqüências de cada classe de valores de incremento de peso, nota-se que a maior parte dos indivíduos do tratamento B (59\%) obtiveram um incremento de peso moderado ao longo de 30 dias, de 1 a 5\%; 29\% dos indivíduos apresentaram incremento de 6 a $10 \%$ do peso e apenas $12 \%$ dos animais apresentaram incremento de peso maior que $10 \%$ (Fig. 8). Os animais do tratamento A exibiram um padrão de histograma semelhante ao tratamento $\mathrm{B}$, embora com frequiências mais altas nas classes onde o incremento de peso foi maior: $17 \%$ dos indivíduos se enquadraram 
na classe de valores onde o incremento de peso foi maior que $10 \%, 39 \%$ atingiram incremento de peso de 6-10\% e $44 \%$ dos animais obtiveram incremento de peso de 1 $5 \%$. No padrão de histograma exibido por animais do tratamento $\mathrm{C}$, a maior parte dos indivíduos (53\%) obtiveram incremento de 6-10\% do peso, 29\% apresentaram incremento de mais de $10 \%$ do peso (correspondendo à maior freqüência alcançada nessa faixa de valores) e apenas $18 \%$ dos animais tiveram incremento de peso de $1-5 \%$.

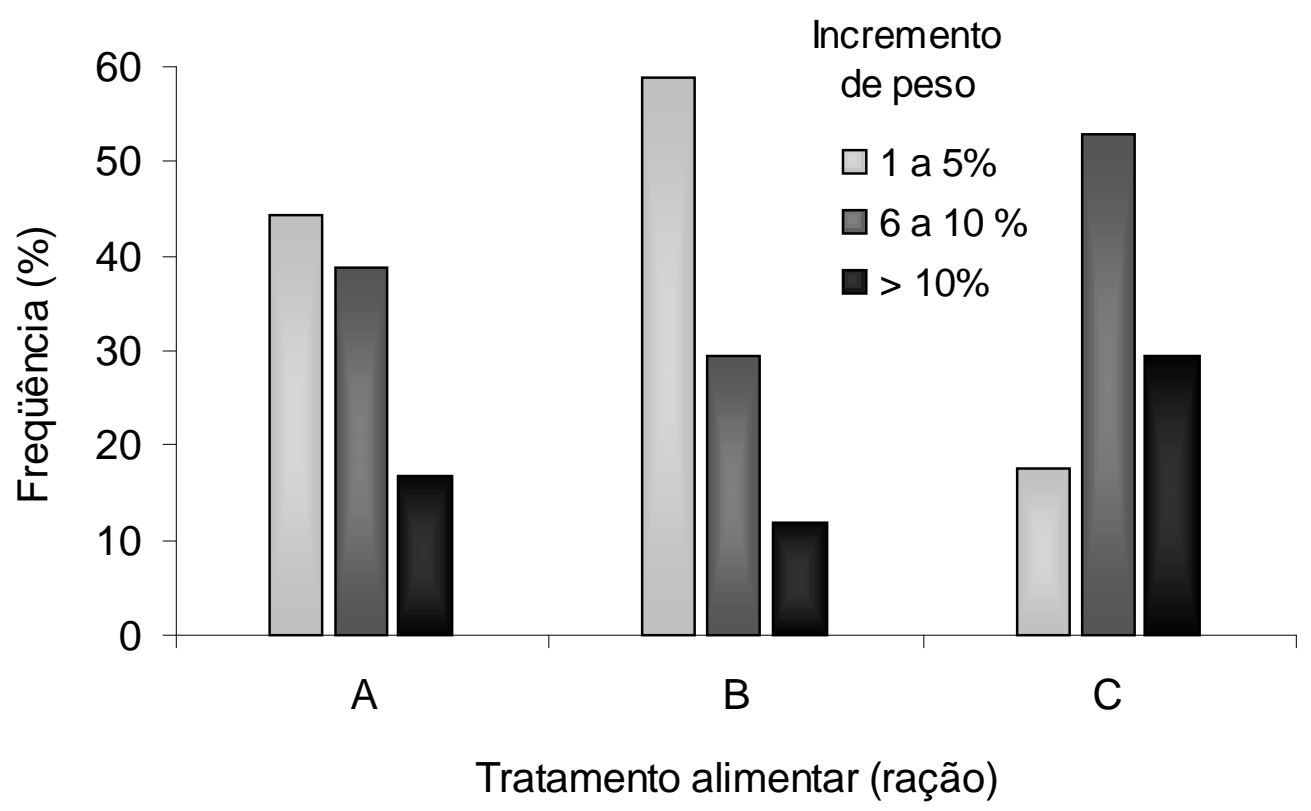

Fig. 8: Incremento de peso de Farfantepenaeus paulensis, em porcentagem (\%). Os histogramas correspondem às freqüências (\%) de cada classe de valores de incremento de peso, ao longo de 30 dias, a partir de um número amostral (n) de 18, 17 e 17 indivíduos, submetidos aos tratamentos alimentares $\mathrm{A}, \mathrm{B}$ e $\mathrm{C}$, respectivamente. As condições experimentais de temperatura e salinidade foram de $23^{\circ} \mathrm{C}\left( \pm 2^{\circ} \mathrm{C}\right)$ e $35 \%$. 


\subsubsection{Correlação entre a digestibilidade proteica in vivo e in vitro}

A previsibilidade do método in vitro (medido pelo grau de hidrólise proteica das rações) foi verificada por meio de uma análise de regressão, em que se comparou os dados (in vivo) de digestibilidade aparente das proteínas (DAP\%) das rações com o grau de hidrólise (in vitro) das proteínas desses mesmos alimentos fornecidos. No entanto, provavelmente as características da ração $\mathrm{B}$ interferiram de modo diferencial na alimentação dos camarões e possivelmente afetaram os resultados de DAP\%, o que motivou sua exclusão na análise, apesar dos pontos ainda estarem presentes no gráfico (Fig. 9). Considerando-se apenas as rações A e C para a análise, foi obtida correlação significativa $(\mathrm{p}<0,05)$ com $\mathrm{R}^{2}=0,55$ e $\mathrm{R}$ de Pearson $=0,74$ para os parâmetros analisados.

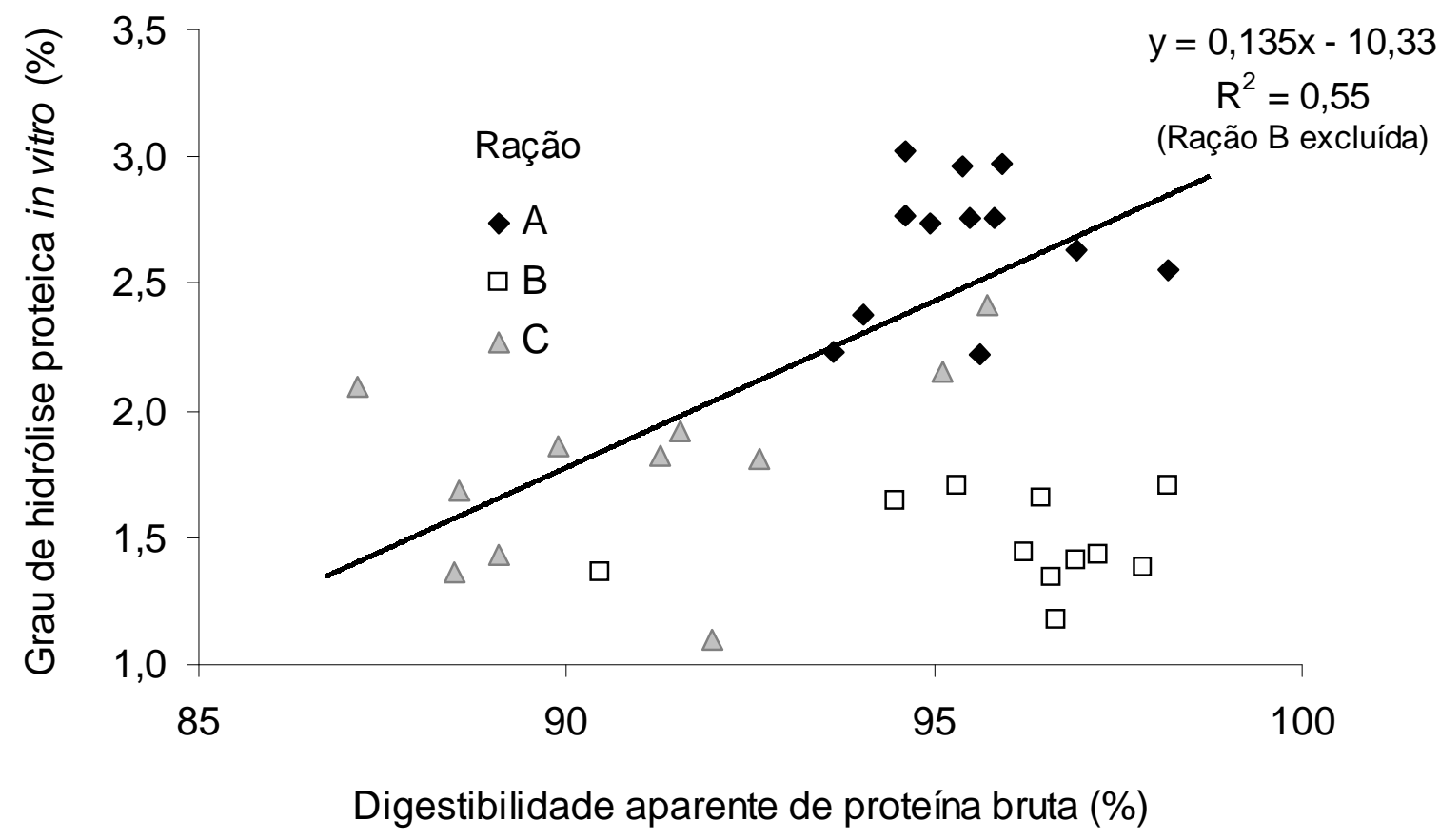

Fig. 9: Correlação entre a digestibilidade aparente (in vivo) de proteína bruta e o grau de hidrólise in vitro das proteínas das rações com extratos de hepatopâncreas de $F$. paulensis. A ração $B$ foi excluída da análise de regressão devido às suas características, que provavelmente afetaram os resultados de digestibilidade aparente de proteína bruta. As condições experimentais de temperatura e salinidade foram de $23^{\circ} \mathrm{C}\left( \pm 2^{\circ} \mathrm{C}\right)$ e $35 \%$. 


\section{Discussão}

\subsection{Digestibilidade de proteína em função da ontogênese}

Em relação aos resultados obtidos quanto ao tipo de substrato empregado, os valores de DH\% proteico da caseína foram semelhantes aos apresentados por Lemos et al. (2004), que testaram o DH\% proteico de rações e ingredientes para essa mesma espécie. Os valores de DH\% de proteína da farinha de peixe LT94 obtidos no presente trabalho se enquadraram na média atingida por outras demais farinhas de peixe testadas por esses mesmos autores. As farinhas de peixe LT (low temperature) são assim designadas devido ao modo de processamento, realizado sob baixas temperaturas (Anderson et al., 1997). Embora essas farinhas de peixe sejam ingredientes considerados frescos e de boa qualidade, seu DH\% proteico foi relativamente baixo, com valores de 2 a 3\%, comparáveis aos apresentados por algumas das farinhas empregadas no trabalho realizado por Lemos et al. (2004). Apesar da caseína não ser considerada uma proteína adequada para promover o crescimento em períodos superiores a 1 mês (Cuzon et al., 1994), ainda é um dos substratos mais utilizados em testes enzimológicos e de determinação de DH\% (Dimes \& Haard, 1994; Ezquerra et al.,1997a; García-Carreño et al., 1996). De modo geral, os ingredientes purificados como a caseína são mais digeríveis do que ingredientes de dietas práticas (Akiyama et al., 1989; Lee \& Lawrence, 1997), como foi confirmado pelos presentes resultados.

Dos resultados de DH\% da caseína obtidos com o uso dos extratos enzimáticos de $F$. paulensis de 1, 3, 8 e 12 meses de idade, houve diferença significativa apenas quando se comparou os resultados provenientes dos animais de 3 e 8 meses. Considerando-se que o padrão de DH\% obtido no decorrer de 12 meses foi oscilatório, isto é, de aumento seguido por queda nos valores, inicialmente seria difícil de encontrar 
uma hipótese que explicasse algum padrão ontogenético da espécie estudada. Neste sentido, estudos adicionais são necessários. Em um trabalho realizado com peneídeos (Smith et al., 1985), foi avaliado o efeito da fonte e dos níveis de proteína de rações experimentais sobre a digestibilidade aparente (ou digestibilidade in vivo) em camarões da espécie Litopenaeus vannamei de três tamanhos: pequenos $(4,0 \pm 0,9 \mathrm{~g})$, médios $(9,8$ $\pm 1,8 \mathrm{~g})$ e grandes $(20,8 \pm 1,0 \mathrm{~g})$. Através da análise dos resultados, os autores concluíram que a digestibilidade de proteína variou independentemente do tamanho dos camarões (e consequientemente, da idade) ou da dieta testada, fato semelhante ao obtido pelo método in vitro no presente estudo.

Em relação à pesquisa nutricional aplicada a peixes, Dimes \& Haard (1994) investigaram o efeito da idade sobre a digestibilidade proteica e aplicaram o método $\mathrm{pH}$-stat para verificar a possibilidade de haver diferenças nos resultados de $\mathrm{DH} \%$ de proteínas quando se empregavam enzimas do ceco pilórico de trutas de tamanhos (idades) diferentes. As enzimas provenientes de animais de $50 \mathrm{~g}$ resultaram em baixo valor de $\mathrm{DH} \%(17,5 \pm 0,5 \%)$ de caseína, quando comparado às enzimas provenientes de animais de 500g (DH\% de 19,5 \pm 0,5\%). No entanto, em um outro experimento desse mesmo trabalho, os autores questionaram se haveria alteração nos valores de $\mathrm{DH} \%$ das proteínas da caseína durante o crescimento de animais de 9g, em um período de 15 meses. Foi verificado que em relação ao valor de DH\% apresentado no início do experimento (17,8\%), a utilização de enzimas digestivas provenientes de animais mais crescidos resultaram em valores de DH\% maiores (17,9 a 22,1\%). No entanto, os resultados de $\mathrm{DH} \%$ reportados nem sempre apresentaram uma relação de incremento de valor conforme o passar do tempo e sim, uma seqüência de oscilações (aumentos seguidos de diminuições) nos valores de $\mathrm{DH} \%$ a partir do momento em que os peixes atingiam o $6^{\circ}$ mês de experimento. Infelizmente, nesse segundo experimento não há 
informação a respeito das possíveis diferenças estatísticas dos resultados de $\mathrm{DH} \%$ no decorrer do tempo experimental.

No trabalho de revisão sobre digestibilidade de nutrientes para crustáceos, Lee \& Lawrence (1997) acreditam que possam haver diferenças na digestibilidade relativas à idade, onde os camarões mais novos apresentariam maior digestibilidade alimentar do que animais mais velhos. No entanto, pelos fatos anteriormente apresentados, percebese que a relação entre o tamanho ou idade dos animais para a determinação da digestibilidade in vitro de proteína ainda não é muito evidente, em parte porque essa relação parece não ter sido ainda esclarecida mesmo em experimentos de digestibilidade in vivo.

Quanto aos resultados aqui obtidos para $F$. paulensis, é certo o fato de que a caseína contribuiu para a percepção da diminuição significativa no valor de DH\%, quando se comparou os resultados obtidos com o uso de enzimas de animais de 3 e 8 meses de idade. Embora ainda sejam necessários maiores estudos quanto à relação entre a idade dos juvenis e o $\mathrm{DH} \%$ de proteínas, do ponto de vista prático essa questão possivelmente não comprometeria os resultados de avaliação da qualidade de alimentos (ingredientes práticos ou formulações). Isso foi observado no caso das análises de DH\% da farinha de peixe LT94 que resultou em amplitudes de DH\% bastante inferiores que os da caseína, insuficiente para gerar diferenças significativas que pudessem ser detectáveis, independentemente do estágio ontogenético dos camarões. Para que se obtenha uma melhor definição, ao menos para $F$. paulensis, seria recomendável que em experimentos futuros se verificasse se há diferenças significativas no $\mathrm{DH} \%$ obtido com o uso de enzimas digestivas de animais com idades intermediárias a 3 e 8 meses (devido ao que se constatou nos resultados) e também em idades superiores a 12 meses, com o emprego de caseína e de um outro ingrediente ou ração como substrato. 


\subsection{Digestibilidade de proteína em função do estado nutricional}

O fato do grau de hidrólise proteica independer do estado nutricional dos camarões-rosa, como se verificou nos resultados obtidos, simplifica a aplicação desse método in vitro, pois minimiza os requisitos necessários para a escolha de hepatopâncreas que sejam adequados para a preparação dos extratos enzimáticos. Em relação à literatura consultada, embora existam trabalhos que associem a fonte nutricional com a atividade enzimática (Ezquerra et al., 1997b; Pedroza-Islas et al., 2004) ou modulação na atividade enzimática em resposta ao tipo de dieta (Le Vay et. al., 2001), não é muito fácil encontrar uma situação em que se avalia a digestibilidade proteica in vitro de um animal submetido a jejum, pois os resultados apresentados nesse trabalho foram possíveis de serem executados apenas sob condições laboratoriais. Durante as determinações de atividade enzimática dos extratos de hepatopâncreas para a posterior utilização nas análises in vitro de digestibilidade proteica, também não se constatou alteração significativa na atividade enzimática associada ao estado de jejum. Pelos fatos observados nesse experimento, pode-se dizer que, sob um ponto de vista inicial, não houve influência no uso do hepatopâncreas para a determinação in vitro do grau de hidrólise de proteínas.

\subsection{Digestibilidade de proteína em função da fonte nutricional}

Nesse experimento, os resultados demonstraram que o grau de hidrólise de proteínas independeu da utilização de enzimas digestivas provenientes de animais alimentados com dietas diferentes (no caso, rações comerciais). O que motivou a realização desse experimento foi justamente o fato do método in vitro de avaliação de proteínas com uso de extrato de hepatopâncreas ter sido questionado por alguns autores (Divakaran et al., 2004), no que dizia respeito à limitação de seu uso. Foi sugerido que o 
método deveria ser aplicado somente em casos em que se utilizam extratos de hepatopâncreas de animais que se alimentaram dos mesmos substratos proteicos empregados na análise in vitro. No entanto, o artigo não especifica qual foi a padronização da atividade enzimática utilizada, dificultando a análise das considerações feitas.

Em um dos trabalhos pioneiros (Ezquerra et al., 1997b) que aplicou o método de pH-stat com uso de enzimas retiradas da própria espécie sob estudo (Litopenaeus vannamei) para avaliar a qualidade da proteína de vários alimentos, também se verificou que o grau de hidrólise proteica in vitro não diferia quando se utilizavam enzimas digestivas de indivíduos que se alimentaram de diferentes dietas. No entanto, um outro estudo envolvendo a espécie L. vannamei demonstrou que pode haver influência da fonte nutricional quando os camarões são alimentados com suplementos contendo hidrolisados proteicos. A hidrólise parcial de algumas matérias primas por ação enzimática é empregada para que ocorra aumento da digestibilidade proteica. $\mathrm{O}$ uso de enzimas digestivas de camarões alimentados com tais suplementos alimentares resultou, de modo geral, em um valor maior de DH\% de proteínas do que com o uso de enzimas digestivas de camarões do grupo controle, que foram alimentados sem suplemento (Córdova-Murueta \& García-Carreño, 2002). O emprego de amostras contendo proteínas hidrolisadas pode interferir na avaliação da digestibilidade in vitro pelo método do pH-stat (Dimes et al.,1994a), uma vez que esse método contabiliza justamente a quantidade de ligações peptídicas hidrolisáveis (Shipton \& Britz, 2002), podendo não ser adequado para analisar amostras que tenham sido submetidas a este tipo de processamento. Também a presença de aminoácidos livres podem diminuir o substrato disponível para a ação de enzimas, especialmente se os sítios específicos de ligação das enzimas na cadeia de proteína forem previamente hidrolisados (Córdova- 
Murueta \& García-Carreño, 2002).

Em relação à técnica aplicada a peixes, Dimes \& Haard (1994) também verificaram se a fonte alimentar recebida pelos animais poderia afetar a capacidade hidrolítica das enzimas digestivas, utilizando caseína como substrato. Com exceção de duas das três dietas que continham adição de $0,1 \%$ de enzima, as demais quatro dietas testadas não apresentaram diferença estatística quanto ao $\mathrm{DH} \%$. Provavelmente, a adição de enzima nas dietas pode ter interferido no sistema de regulação de enzimas proteolíticas dos animais, surtindo o mesmo efeito dos suplementos de proteínas hidrolisadas que foi descrito naquele trabalho apresentado por Córdova-Murueta \& García-Carreño (2002). Além de provocar alterações na capacidade de avaliação da qualidade de proteínas pelo método pH-stat, é possível que a utilização de proteínas parcialmente hidrolisadas possa ocasionar algum tipo de ajuste no sistema de regulação enzimática dos animais, maximizando a capacidade proteolítica para melhor utilizar e absorver essas moléculas mais digeríveis. Essa hipótese poderia explicar a alteração (aumento) na capacidade de hidrólise proteica das enzimas digestivas em decorrência da ingestão de alimentos parcialmente hidrolisados.

Em vista aos fatos apresentados, pode-se afirmar que, desde que os animais não sejam alimentados com produtos pré-hidrolisados ou que contenham suplementação enzimática, a fonte nutricional parece não interferir nos resultados de $\mathrm{DH} \%$ das proteínas. 


\subsection{Cultivo experimental com rações comerciais e correlação entre a digestibilidade in vivo (DAP\%) e in vitro (DH\%)}

\subsubsection{Taxa de lixiviação das rações}

A lixiviação é um aspecto importante a ser abordado em estudos nutricionais, por poder prejudicar a qualidade da água utilizada no cultivo, devido à desintegração do alimento. Além do desperdício de nutrientes, a lixiviação pode gerar aumento nos custos com alimentação e afetar a produtividade de cultivo, a saúde dos animais (Obaldo et al., 2002) e o meio ambiente. A taxa de lixiviação encontrada para as três rações, em torno de $17,5-18 \%$ foi relativamente elevada, embora o longo procedimento realizado para sua determinação, como: imersão em água marinha por $2 \mathrm{~h}\left(23 \pm 2{ }^{\circ} \mathrm{C} ; 35 \%\right)$, coleta de material através de sifonação, duas transferências para recipientes diferentes, lavagem com água destilada, congelamento e descongelamento do material armazenado, remoção de sais e filtragem dos sólidos filtração e secagem em estufa $\left(65^{\circ} \mathrm{C}\right)$, contribuiu para a obtenção desses altos índices.

A lixiviação do alimento também pode levar a erros significativos na determinação de valores de digestibilidade (Sudaryono et al., 1996; Lee \& Lawrence, 1997) devido, por exemplo, à superestimação dos valores de ingestão em decorrência da dissolução do alimento na água e devido ao processos envolvidos na obtenção das sobras de ração, em que podem ocorrer perda de materiais, ocasionando menor quantidade de sobras a serem recuperadas e conferindo a falsa impressão de que o alimento foi ingerido pelo indivíduo experimental. No entanto, como um dos objetivos do trabalho foi a análise da possível diferença entre os tratamentos alimentares e pelo fato dos índices de lixiviação das três rações terem sido bastante semelhantes, provavelmente os resultados de ingestão, digestibilidade de matéria seca e 
digestibilidade aparente de proteínas também foram afetados pelas mesmas condições metodológicas, sem uma alteração qualitativa que pudesse comprometer a comparação do desempenho dos tratamentos alimentares no cultivo experimental. De qualquer modo, a utilização de índices de lixiviação como forma de correção nos cálculos de ingestão de ração e consequientemente, nas determinações de digestibilidade, podem ter contribuído para minimizar, à medida do possível, possíveis desvios nas estimativas realizadas, que podem ocorrer em estudos nutricionais envolvendo espécies aquáticas.

\subsubsection{Sobrevivência}

A sobrevivência é um índice comumente empregado em estudos nutricionais (D’Abramo \& Castell, 1997). No entanto, há argumentos de que a qualidade do alimento raramente possa causar algum mal à saúde do camarão (Cuzon et al.,1994). De fato, em relação ao presente trabalho, não houve nenhuma morte de animal associada a qualquer uma das três rações utilizadas, mesmo entre aqueles indivíduos que não apresentaram ganho de peso no período experimental decorrido (57 dias). Entretanto, em um cultivo a longo prazo, possivelmente a sobrevivência pudesse ser um fator indicativo da qualidade ou deficiência nutricional dos alimentos testados.

\subsubsection{Taxa de ingestão alimentar}

Devido à potencial fonte de erro em determinações de digestibilidade, que provém da quantidade relativamente pequena de alimento que é consumido diariamente por cada indivíduo (Smith \& Tabrett, 2004) e pelas dificuldades metodológicas, a determinação do consumo de alimento ainda é considerado um problema que compromete a validade de experimentos (Cuzon \& Aquacop, 1998). Para a realização de um dos principais objetivos do trabalho, que foi o estudo da digestibilidade aparente 
de proteínas, foi feita a opção pelo médodo gravimétrico (ou de coleta total), que consiste no recolhimento de todas as sobras de alimento não ingerido e das fezes resultantes e na pesagem total (gravimétrica) de cada um desses materiais. Teoricamente, esse método seria o mais apropriado, embora manter separadamente as sobras alimentares e as fezes torna-se o principal desafio para sua execução (Lee \& Lawrence, 1997). Por este motivo, o pequeno período de $2 \mathrm{~h}$ diárias destinadas à alimentação dos animais foi necessário, devido ao comportamento alimentar do camarão, que fragmenta e manipula o alimento, agravando ainda mais a lixiviação (Cruz-Suárez, 1996; D’Abramo \& Castell, 1997) e por essa necessidade de se manter o alimento e as fezes separados, que torna impraticável o acesso irrestrito ao alimento. Também para minimizar mudanças na composição do alimento devido à lixiviação antes do consumo no tanque, foi necessário fazer com que o camarão se alimentasse logo que a ração fosse ministrada, o que ocorre apenas se o indivíduo estiver relativamente faminto (Smith \& Tabrett, 2004).

Quanto ao manejo alimentar, apesar do "Protocolo para determinação da digestibilidade de nutrientes e ingredientes para dietas" (D’Abramo \& Castell, 1997) sugerir duas alimentações diárias, cada uma com período inferior a 1h, a recomendação não foi possível de ser seguida pelo fato dos animais demorarem muito tempo para eliminarem completamente as fezes. A quantidade de alimento diário fornecido $(8 \%$ do peso corpóreo) aos juvenis durante todo o período de cultivo (57 dias) foi em excesso, pois sempre se verificou a presença de sobras de ração ao final do período de alimentação (2h diárias). Em virtude do pequeno tempo diário dispendido para a alimentação, a taxa de consumo foi relativamente baixa, o que tornaria complicada a comparação desses resultados com os de trabalhos cujos objetivos fossem o de testar dietas e ingredientes que pudessem proporcionar um bom desempenho de cultivo. 
Assim, foram comparados os presentes resultados de ingestão com os de um trabalho destinado ao estudo do balanço energético de F. paulensis (Lemos et al., 2003). Apesar dos dados de ingestão terem sido fornecidos por indivíduo e não em relação ao peso corpóreo de animal, a conversão aproximada do consumo de alimento por peso corpóreo foi estimada em $0,016 \mathrm{~g}$ de peso úmido de ração/g de camarão/dia, para animais de 6,91 a 11,00g (peso médio de 8,82g). Esse valor foi intermediário ao obtido no presente estudo: 0,0182; 0,0146 e 0,020g de peso úmido de ração/g de camarão/dia, para as rações A, B e C, respectivamente.

Quanto à análise dos resultados obtidos para cada tratamento alimentar, a taxa de ingestão da ração $C$ foi ligeiramente maior do que a ração A, porém suficiente para gerar uma diferença significativa $(\mathrm{p}<0,05)$. Considerando-se que todos os indivíduos estiveram sujeitos às mesmas condições ambientais e de manejo, um dos motivos que explicaria tal fato seria a própria característica do produto $\mathrm{C}$, que supostamente teria despertado maior interesse por parte dos animais, motivando a ingestão de uma quantidade maior dessa ração do que em relação aos demais tratamentos alimentares. Esse fato poderia estar vinculado à palatabilidade do produto. Esta propriedade é um dos fatores nutricionais menos estudados, mas que também influi na taxa de consumo alimentar, pois uma vez que a ingestão precede a digestão, a palatabilidade (sabor, textura, tamanho e forma) de um alimento estabelece quais nutrientes estarão disponíveis para digestão (Lee \& Lawrence, 1997), sendo um fator crítico em determinações que envolvem o consumo alimentar (Cruz-Suárez, 1996).

Os prováveis motivos que justificariam a baixa ingestão do produto $\mathrm{B}$ poderiam ser atribuídos às próprias características desse alimento, como uma textura notavelmente dura e compacta. Ao final do período de alimentação foram observadas quantidades maiores de sobras intactas de ração (apenas levemente hidratadas) nos 
aquários de animais que receberam esse tratamento alimentar, diferentemente dos demais grupos, onde parte considerável das sobras eram compostas por migalhas (decorrente da manipulação pelo animal) ou por material apresentando fragmentação (devido à expansão das partículas alimentares, ocasionada pela hidratação). Em um outro estudo também se constatou que essas propriedades físicas alimentares, como textura e capacidade de hidratação, influenciam no consumo de ração, pois os alimentos que apresentaram maior capacidade de hidratação e menor dureza foram também as mais consumidas, com obtenção de correlações altas entre consumo e hidratação da ração $\left(R^{2}=0,95\right)$ e entre consumo e dureza da ração $\left(R^{2}=-0,95\right)$ (Cerecer-Cota et al., 2005). Com base nos fatos anteriores, supõe-se que o alimento B talvez necessitasse de um tempo maior de hidratação para que pudesse oferecer maior facilidade de fragmentação e ingestão pelos indivíduos. Além de sua textura relativamente mais dura, o produto B também apresentou um teor de umidade $40 \%$ menor do que as demais rações (Tabela 4). Porém, como houve a necessidade de oferecer as mesmas condições de alimentação para os camarões nos três tratamentos alimentares testados, não foi possível verificar se um aumento no período de imersão da ração B resultaria em uma maior taxa de consumo desse alimento pelos indivíduos. Em outros trabalhos, também relatou-se a diminuição no consumo de certas dietas, dependendo da forma de processamento, provavelmente por alterar as propriedades físicas do alimento (Booth et al., 2000; Cruz-Suárez et al., 2001; Venou et al., 2003). 


\subsubsection{Relação entre a taxa de ingestão e a digestibilidade aparente de}

\section{proteína}

Através da análise dos resultados desses dois parâmetros, pode-se observar que ambos apresentaram uma relação oposta. A taxa de consumo alimentar apresentada pelos animais submetidos aos três tratamentos alimentares resultou na seguinte seqüência decrescente de valores: ração $\mathrm{C}>\mathrm{A}>\mathrm{B}$. No entanto, o ranking para a digestibilidade proteica mostrou uma seqüência contrária à citada anteriormente: ração B > A > C. A relação observada pode ser decorrente de dois fatores: além da morfofisiologia do trato digestivo, que pode afetar a disponibilidade dos nutrientes, também as condições ambientais do cultivo e as características físicas e nutricionais do alimento podem afetar a digestibilidade (Lee \& Lawrence, 1997). A palatabilidade é uma dessas propriedades que pode interferir nos índices de digestibilidade, por afetar diretamente as taxas de ingestão. Uma alta taxa de consumo implica em um rápido trânsito alimentar pelo sistema digestório e menor tempo relativo para que os nutrientes possam ser absorvidos, diminuindo a eficiência de digestão (Kureshy \& Davis, 2002). Esses fatores justificariam os motivos pelos quais a ração B obteve o maior índice de DAP\% e a menor taxa de consumo alimentar; a ração C, o menor índice de DAP\% e a maior taxa de consumo alimentar e por fim, a ração A, índice de DAP\% e taxa de consumo intermediárias entre as demais rações.

Além da palatabilidade, outro fator relacionado à digestibilidade pode ser atribuído ao modo de processamento pelo qual o produto é submetido durante a fabricação, por determinar as propriedades físicas e nutricionais do alimento. O calor e a pressão, por exemplo, são condições que ajudam na inativação de substâncias inibidoras de proteases e melhoram a biodisponibilidade dos nutrientes (Watanabe, 2002) e a digestibilidade de proteínas (Hardy \& Gatlin, 2002). 


\subsubsection{Digestibilidade aparente de matéria seca e digestibilidade de}

\section{proteínas}

Pode-se observar que as médias dos resultados de digestibilidade aparente de matéria seca para as três rações $\left(\mathrm{DAMS}_{\mathrm{A}}=86,63 \% ; \mathrm{DAMS}_{\mathrm{B}}=89,55 \% ; \mathrm{DAMS}_{\mathrm{C}}=\right.$ $80,94 \%)$ foram bem menores do que as de digestibilidade aparente de proteína $\left(\mathrm{DAP}_{\mathrm{A}}=\right.$ 95,51\%; $\left.\mathrm{DAP}_{\mathrm{B}}=96,24 \% ; \mathrm{DAP}_{\mathrm{C}}=91,19 \%\right)$, provavelmente devido à importância que as proteínas representam para os crustáceos peneídeos (Shiau, 1998), em comparação com os baixos requerimentos de carboidratos e lipídeos (Dall et al., 1990). Assim, o aproveitamento da proteína ingerida deve ser maximizado em relação aos demais nutrientes disponíveis no alimento. Embora os resultados de digestibilidade das rações A e B não tenham apresentado diferenças significativas entre si ( $p>0,05)$, os índices de DAMS\% mantiveram a mesma seqüência de valores de média em relação à DAP\% (índices das rações apresentaram valores de $\mathrm{B}>\mathrm{A}>\mathrm{C}$ ).

\subsubsection{Relação entre incremento de peso e digestibilidades (aparente de}

\section{proteínas e de matéria seca)}

A forma pela qual os crustáceos crescem, de modo descontínuo, isto é, com rápido ganho de peso devido à absorção de água após o momento de muda, seguido por um período longo com pouco incremento tecidual, torna mais difícil a comparação entre tratamentos alimentares (D’Abramo \& Castell, 1997). No entanto, o período em que os animais estiveram expostos aos tratamentos alimentares foi relativamente longo (57 dias no total, entre o tempo de adaptação e o período experimental) e, portanto, suficiente para que todos os animais passassem por 2 a 4 períodos de mudas e inter-mudas. Por este motivo, pode-se considerar que os dados obtidos mantiveram homogeneidade entre as coletas em grande parte, pois foram resultantes das mesmas interferências 
metodológicas.

Comparando-se os tratamentos alimentares, a ração A obteve uma relação mais equilibrada em relação ao crescimento e digestibilidade de matéria seca e de proteínas. Seu aproveitamento quanto à absorção de nutrientes foi relativamente alto e não apresentou diferenças significativas $(\mathrm{p}>0,05)$ em relação à ração $\mathrm{B}$. Ao mesmo tempo, o incremento de peso atingido pelos animais foi comparável não só à ração $\mathrm{B}$, mas também em relação à ração $\mathrm{C}(\mathrm{p}>0,05)$. A digestibilidade por si só, não pode ser relacionada ao crescimento. Outros fatores como balanço de aminoácidos e palatabilidade podem afetar o resultado geral (Forster et al., 2003). E mesmo que um alimento apresente baixa digestibilidade, o crescimento pode ser compensado por meio de uma maior taxa de consumo (Smith et al., 1985), o que provavelmente ocorreu com os animais do tratamento $\mathrm{C}$ do presente estudo.

Em relação ao tratamento alimentar C, pode-se afirmar que o alto crescimento dos camarões foi alcançado às custas de um consumo maior, embora com aproveitamento menor (desperdício de insumo e perda desse material para o meio ambiente). De um modo geral isto pode não ser recomendável, já que em longo prazo, os gastos gerados no cultivo com esse tipo de alimento podem superar os benefícios, devido aos riscos de comprometer a produtividade e a saúde do animal (Hardy \& Gatlin, 2002; Tacon, 2002), além da qualidade dos efluentes gerados, que podem impactar a biota local, caso corpos d'água sejam atingidos (Figueiredo et al., 2005).

\subsubsection{Correlação entre nitrogênio fecal e digestibilidade aparente de}

\section{proteína bruta}

A partir dos resultados obtidos pela correlação entre os dados de nitrogênio fecal e digestibilidade aparente de proteína bruta dos três tratamentos alimentares, podese dizer que a análise do teor de $\mathrm{N}$ ou de proteína bruta presente nas fezes possui 
potencial de diagnóstico da qualidade proteica das rações, pois os dados foram representativos quanto à digestibilidade aparente de proteína bruta. Outros autores também afirmaram que a análise da proteína fecal pode ser um indicativo da produtividade dos animais cultivados, pois os indivíduos que eliminaram níveis altos de proteína foram também os que apresentaram menor produtividade (Nates \& Tacon, 2005). Estas constatações foram importantes, à medida em que podem ajudar a diminuir a necessidade de se cumprir experimentos prolongados e trabalhosos de cultivo com coleta total de materiais (sobras alimentares e fezes) e possivelmente simplificar a operação a ser realizada, através da coleta parcial de material fecal produzido pelos animais.

\subsubsection{Produção fecal e de nitrogênio fecal}

Uma vez que a maior parte da origem da descarga de nutrientes na água de cultivo origina-se no alimento que é oferecido, os esforços para a mitigação desses impactos devem ser concentrados no foco nutricional (Cho \& Bureau, 2001; Hardy \& Gatlin, 2002; Tacon \& Forster, 2003). Atualmente, vem aumentando o número de trabalhos com enfoque em diagnósticos e alternativas de mitigação dos impactos provocados pela aqüicultura (Burford \& Williams, 2001; Cho \& Bureau, 2001; Tacon, 2002; Jackson et al., 2003; Figueiredo et al., 2005), com vistas inclusive, à sustentação da própria atividade econômica. Um dos principais meios para diminuir esses resíduos, minimizando também a perda de nutrientes e o desperdício de alimento, é através da escolha de alimentos que apresentem alta digestibilidade (Hardy \& Gatlin, 2002; Tacon, 2002), como as rações testadas A e B, que resultaram nos melhores índices de digestibilidade de matéria seca e de proteínas, decorrente do aumento na quantidade de materiais assimilados resultantes da digestão. Como consequiência, apresentaram 
redução no volume de fezes e nitrogênio fecal. Assim como nos demais parâmetros, novamente as características da ração B podem ter interferido nos resultados de uma menor taxa de liberação de fezes e de material nitrogenado. Algumas formas de processamento de alimentos que implicam no aumento da digestibilidade são estratégias adotadas para a produção de alimentos aquáticos que possam gerar menor volume de descarga de nutrientes nos sistemas hídricos (Hardy \& Gatlin, 2002). Em relação ao tratamento $\mathrm{C}$, embora os animais que receberam esse alimento terem crescido às custas de uma alta taxa de ingestão, foram também os que mais eliminaram material fecal.

Os dados obtidos foram comparáveis aos apresentados por Lemos et al. (2003), que verificaram que a taxa de produção fecal de $F$. paulensis foi de $0,0142 \mathrm{~g}$ de peso úmido diário de ração por camarão, mas considerando-se que os juvenis do trabalho daqueles autores tinham entre 6,91 a $11 \mathrm{~g}$ (peso médio de 8,82g), estima-se que a taxa específica de liberação fecal diária seja de 0,0016g de peso seco de fezes/g de camarão, valor dentro da faixa encontrada nos resultados do presente trabalho: $0,0023 \pm 0,0009 \mathrm{~g}$; $0,0014 \pm 0,0006 \mathrm{~g}$ e $0,0034 \pm 0,0003 \mathrm{~g}$ de peso seco de fezes/g de camarão; para as rações $\mathrm{A}, \mathrm{B}$ e $\mathrm{C}$, respectivamente.

\subsubsection{Correlação da digestibilidade proteica in vivo e in vitro}

Embora uma das metas iniciais desse estudo fosse a de testar a capacidade de previsão da qualidade das rações pelo método in vitro, certamente a correlação de $\mathrm{R}^{2}=$ 0,55 não foi mais alta devido à complexidade de fatores que afetam um cultivo experimental, como foi o caso das características físicas das rações (Lee \& Lawrence, 1997). Ao contrário dos métodos in vitro, a atratividade, palatabilidade, estabilidade e textura consideradas ideais para o despertar do consumo, só podem ser avaliadas pelos próprios animais estudados. E desse conjunto de características depende a aceitação do 
alimento e a ingestão (Lee \& Meyers, 1997), cujo valor é aplicado no cálculo de digestibilidade in vivo. A exclusão da ração B na análise de correlação acabou sendo motivada por seus prováveis efeitos sobre a alimentação dos camarões. Embora essa ração tenha sido escolhida justamente para a comparação da performance de cultivo com as demais rações, além da baixa ingestão verificada, suas propriedades físicas possivelmente acabaram por afetar também a fisiologia da digestão, resultando em uma digestibilidade in vivo de proteínas (DAP\%) superior à prevista pelo método in vitro.

Apesar da correlação de $\mathrm{R}^{2}=0,55$ obtida pela comparação entre os dados de digestibilidade proteica in vivo e in vitro, há autores que testaram esta mesma técnica in vitro com enzimas provenientes das espécies estudadas e obtiveram valores mais altos como $\mathrm{R}^{2}=0,82$ (Dimes \& Haard, 1994) e $\mathrm{R}^{2}=0,87$ (Dimes et al., 1994a), no caso de salmonídeos e $\mathrm{R}^{2}=0,77$ (Ezquerra et al., 1997a; 1998), no caso do peneídeo Litopenaeus vannamei. No entanto, a técnica in vivo empregada por estes autores foi a do marcador (óxido crômico) misturado à ração, que tem sido a metodologia mais comum em estudos de digestibilidade, por não necessitar a coleta total de fezes. Neste caso, os resultados de digestibilidade aparente de proteínas foram calculados pela diferença entre as concentrações iniciais (na ração) e finais do óxido crômico (nas fezes). Talvez a obtenção de um $\mathrm{R}^{2}$ favorável com o uso de marcadores esteja relacionada às prováveis menores susceptibilidades de lixiviação, manipulação das fezes pelos camarões e coprofagia, pois o método necessita de menor quantidade de material fecal para ser coletada e que pode ser recolhida logo que for liberada. No entanto, considera-se que o método gravimétrico adotado nos experimentos realizados possa ser uma opção melhor que o óxido crômico, embora ambos os métodos apresentem erros potenciais para a avaliação de alimentos para crustáceos (Leavitt, 1985; Lee \& Lawrence, 1997). Como um dos objetivos do presente trabalho era testar o método $\mathrm{pH}-$ 
stat com enzimas da própria espécie para verificar a qualidade da proteína de rações comerciais, o método gravimétrico se tornou a única alternativa possível. O uso de marcador implicaria na confecção de rações experimentais com pouca chance de reproduzirem as condições alimentares dos produtos comerciais. Outro aspecto levantado refere-se à necessidade do marcador estar distribuído de forma homogênea no alimento, para que a concentração final da substância nas fezes possa indicar adequadamente a proporção de material absorvido no organismo do camarão. Nesse caso, o uso de marcadores como o óxido crômico nem sempre pode ser adequado, por apresentar densidade específica bem maior que os demais componentes da ração, tendendo a acumular-se na camada inferior do alimento moído (Divakaran, 2005).

Embora parte significativa dos experimentos envolvendo o método do $\mathrm{pH}$-stat tenha gerado bons resultados, houve casos em que foram obtidas baixas correlações, provavelmente por interferências na análise in vitro. Dimes et al. (1994), obtiveram a baixa correlação de $\mathrm{R}^{2}=0,26$ para truta arco-íris, que foi atribuída provavelmente à proteólise ocorrida durante a preparação das amostras. Anderson et al. (1997) que pesquisaram a qualidade de farinhas de peixe para salmão, não obtiveram correlação para a digestibilidade in vivo $\left(\mathrm{R}^{2}=0,14 ; \mathrm{n}=16 ; \mathrm{p}=0,16\right)$ e o método $\mathrm{pH}$-stat, embora esses autores tenham utilizado enzimas comerciais para a análise in vitro. Com relação a camarões marinhos, os presentes resultados corroboram os principais experimentos realizados até o momento com matérias-primas e dietas desde que Ezquerra et al. (1997) encontraram correlação significativa com diferentes tipos de farinha de peixe. Mais recentemente, a correlação entre o grau de hidrólise in vitro de proteínas e o desempenho (crescimento, produção e conversão alimentar) de Litopenaeus vannamei cultivado experimentalmente foi também verificada $\left(\mathrm{R}^{2}=0,70-0,88\right)$ (Lemos et al., 2006). 


\subsubsection{Vantagens e precauções na aplicação do pH-stat}

Entre os fatores que devem ser considerados quanto à sua aplicação está a possibilidade de ocorrer interferências nos resultados quando há utilização de amostras que contenham proteínas hidrolisadas (Dimes et al., 1994a), pois essas substâncias podem interferir na reação de hidrólise afetando os resultados de $\mathrm{DH} \%$, que podem exibir uma correlação inversa com os dados in vivo de digestibilidade de proteína bruta (Córdova-Murueta \& García-Carreño, 2002). Como o método se baseia na mudança de $\mathrm{pH}$ durante o processo de hidrólise das amostras, também há a possibilidade de haver liberação de ácidos graxos durante o processo de digestão in vitro, o que poderia resultar em alterações no resultado (Grabner, 1985). Além disso, o pH-stat opera apenas em uma faixa de $\mathrm{pH}$ alcalino (> que 7,5) por depender dos valores de $\mathrm{pK}$ dos grupos amino e carboxila (Adler-Niessen, 1986). Outra possibilidade é a de que os produtos da hidrólise de proteínas possam interferir na atividade das enzimas digestivas empregadas (Bassompierre et al.,1997).

Em relação aos métodos in vitro existentes, algumas das vantagens atribuídas ao pH-stat têm sido: a possibilidade de utilizar as enzimas da espécie sob estudo, ao invés de enzimas comerciais, proporcionando maior representatividade na obtenção de resultados (Dimes \& Haard, 1994; Dimes et al., 1994a,b; Ezquerra et al., 1997a, 1998; Lemos et al., 2004); a manutenção de um pH estável durante o processo de digestão que evita a desnaturação enzimática (García-Carreño et al., 1996) e dispensa a utilização de altas concentrações de tampões e a possibilidade de quantificar a presença de aminoácidos livres nas amostras antes da adição de enzimas digestivas (Bassompierre et al.,1997). Outro aspecto importante refere-se à obtenção dos resultados de modo rápido através da curva de titulação (Grabner, 1985), o que poderia viabilizar a aplicação dessa técnica in vitro em escala comercial, desde que seus resultados sejam validados por 
meio de testes de cultivo.

\section{Conclusão}

Devido à grande necessidade de se avaliar rapidamente a qualidade nutricional dos alimentos para organismos aquáticos, esforços para a disponibilização de métodos in vitro de avaliação da digestibilidade de nutrientes vem sido recomendada (Tacon, 2002). A técnica in vitro de digestão enzimática foi considerado um dos mais interessantes métodos analíticos propostos para a avaliação da digestibilidade de alimentos aquáticos (Lee \& Lawrence, 1997), incluindo o método pH-stat com o uso de enzimas das próprias espécies (Nates \& Tacon, 2005).

De modo geral, pode-se dizer que a necessidade de aprimoramento do método deve ser um processo contínuo, com questões a serem levantadas e esclarecidas. É importante que também se estude essa técnica in vitro sob a óptica da espécie sob

estudo, devido às variações nos padrões enzimológicos (Lemos et al., 2000) ou fisiológicos que podem existir entre diferentes espécies de peneídeos e que poderiam ocasionar respostas diferentes em relação a um mesmo fator sob investigação. Parte dessas questões começaram a ser examinadas no presente estudo e requerem prosseguimento. Em relação ao camarão rosa $F$. paulensis, pode-se dizer que, nas condições estudadas, não houve maiores restrições em relação à utilização de suas enzimas digestivas para as determinações in vitro das rações comerciais testadas para esta espécie.

Considerando-se que o estudo nutricional é bastante complexo, pois envolve não só a palatabilidade, digestibilidade e absorção, quando se considera o organismo; mas também o balanço de aminoácidos e a biodisponibilidade, quando se considera as propriedades do alimento (García-Carreño et al., 1997), é importante ressaltar que 
nenhum método in vitro deverá ser capaz de substituir os testes de cultivo para a avaliação da digestibilidade de proteínas (Lee \& Lawrence, 1997), pois a avaliação final dos itens anteriormente mencionados só podem ser realizadas pelos próprios animais estudados. Mas sem dúvida é um avanço notável, a julgar pelos resultados satisfatórios obtidos em parte considerável dos experimentos já realizados com o uso do método desde seu desenvolvimento (Pedersen \& Eggum, 1983; Dimes \& Haard, 1994; Ezquerra et al., 1997a; 1998; Shipton \& Britz, 2002). A possibilidade do método contribuir na redução do tempo e dos custos dispendidos nos experimentos de cultivo (Pedersen \& Eggum, 1983; Shipton \& Britz, 2002) pode otimizar a busca por ingredientes, matériasprimas e alimentos (García-Carreño et al., 1997; Lemos et al., 2004) que sejam adequados para o cultivo de espécies autóctones como o camarão-rosa, que pode ser uma alternativa de diversificação comercial e de bons resultados devido a sua natural adaptação fisiológica e evolução às condições ambientais locais (Lemos et al., 2000). 


\section{Referências bibliográficas}

Adler-Nissen, J. 1986. Enzymic Hydrolysis of food proteins. Elsevier, London and New York. 427pp.

Akiyama, D.M.; S.R. Coelho; A.L. Lawrence; E.H. Robinson. 1989. Apparent digestibility of feedstuffs by the marine shrimp Penaeus vannamei Boone. Nippon Suisan Gakkaishi, 55(1): 91-98.

Anderson, J.S; D.A. Higgs; R.M. Beames; M. Rowshandeli. 1997. Fish meal quality assessment for Atlantic salmon (Salmo salar L.) reared in sea water. Aquaculture Nutrition, 3: 25-38.

A.O.A.C. 1984. Official methods of analysis. Association of the Official Analytical Chemists. Arlington, Virginia. 1141pp.

Bassompierre, M.; T. Borresen.; P. Sandfeld; B. Ronsholdt; W. Zimmermann; E. Mclean. 1997. An evaluation of open and closed systems for in vitro protein digestion of fish meal. Aquaculture Nutrition, 3: 153-159.

Booth, M.A.; G.L. Allan; R. Warner-Smith. 2000. Effects of grinding, steam conditioning and extrusion of a practical diet on digestibility and weight gain of silver perch, Bidyanus bidyanus. Aquaculture, 182: 287-299.

Burford, M.A.; K.C. Williams. 2001. The fate of nitrogenous waste from shrimp feeding. Aquaculture, 198: 79-93.

Cerecer-Cota, E.E.; D. Ricque-Marie; F. Mendoza-Cano; M.G. Mieto-López; L.E. Cruz-Suárez; B. Ramírez-Wong; M.G Salazar-García; M. Velasco-Escudero. 2005. Pellet stability, hardness influence feed consumption of pacific white shrimp. Global Aquaculture Advocate, 8(2): 84-86.

Cho, C.Y.; D.P. Bureau. 2001. A review of diet formulation strategies and feeding 
systems to reduce excretory and feed wastes in aquaculture. Aquaculture research, 32: 349-360.

Córdova-Murueta, J.H.; F.L. García-Carreño. 2002. Nutritive value of squid and hydrolyzed protein supplement in shrimp feed. Aquaculture, 210: 371-384.

Cruz-Suárez, L.E. 1996. Digestion en camaron y su relacion con formulacion y fabricacion de alimentos balanceados. In: Avances en Nutrición Acuícola III. Cruz Suárez, L. E.; D. Ricque Marie; R. Mendoza. (Eds.). Memorias 3er. Simposium Internacional de Nutrición Acuícola, Monterrey, Nuevo León, México. pp.207-232.

Cruz-Suárez, L.E.; D. Ricque-Marie; M. Tapia-Salazar; I.M. McCallum; D. Hickling. 2001. Assessment of differently processed feed pea Pisum sativum meals and canola meal Brassica sp. in diets for blue shrimp Litopenaeus stylirostris. Aquaculture, 196: 87-104

Cuzon, G.; J. Guillaume; C. Cahu. 1994. Composition, preparation and utilization of feeds for Crustacea. Aquaculture, 124: 253-267.

Cuzon, G.; Aquacop. 1998. Nutritional review of Penaeus stylirostris. Reviews in Fisheries Science, 6 (1\&2): 129-141.

D’Abramo, L.R.; J.D. Castell. 1997. Research Methodology. In: Crustacean Nutrition. D’Abramo, L.R; D.E. Conklin; D.M. Akiyama. (Eds.). The World Aquaculture Society, Baton Rouge, LA,USA. pp 3-25.

Dall, W.; B.J. Hill; P.C. Rothlisberg; D.J. Sharples. 1990. The Biology of the Penaeidade. Advances in Marine Biology. Academic Press, London, Great Britain. Vol 27. 489 pp.

Dimes, L.E.; N. Haard. 1994. Estimation of protein digestibility - I. Development of an in vitro method for estimating protein digestibility in salmonids (Salmo 
gairdneri). Comp. Biochem. Physiol. 108A: 349-362.

Dimes, L.E.; N. Haard; F.M. Dong; B.A. Rasco; I.P. Forster; W.T. Fairgrieve; R. Arndt; R.W. Hardy; F.T. Barrows; D.A. Higgs. 1994a. Estimation of protein digestibility - II. In vitro assay of protein in salmonid feeds. Comp. Biochem. Physiol. 108A: 349-362.

Dimes, L.E.; F.L. Garcia-Carreño; N.F. Haard. 1994b. Estimation of protein digestibility - III. Studies on the digestive enzymes from the pyloric ceca of rainbow trout and salmon. Comp. Biochem. Physiol. 109A: 349-360.

Divakaran, S.; I.P. Forster; M. Velasco. 2004. Limitations on the use of shrimp Litopenaeus vannamei midgut gland extract for the measurement of in vitro protein digestibility. Aquaculture, 239: 323-329.

Divakaran, S. 2005. Chromic oxide: the inert marker for in vivo digestibility studies in shrimp, problems and solutions. Aquafeeds: Formulation \& Beyond, 2(2): 2829.

Ezquerra, J.M.; F.L. García-Carreño; R. Civera; N.F. Haard. 1997a. pH-stat method to predict protein digestibility in white shrimp (Penaeus vannamei). Aquaculture, 157: 251-262.

Ezquerra, J.M.; F.L. García-Carreño; N.F Haard. 1997b. Effects of feed diets on digestive proteases from the hepatopancreas of white shrimp (Penaeus vannamei). Journal of Food Biochemistry, 21(4): 401-419.

Ezquerra, J.M.; F.L. Garcia-Carreño; O. Carrillo. 1998. In vitro digestibility of dietary protein sources for white shrimp (Penaeus vannamei). Aquaculture, 163: 123136.

Figueiredo, M.C.B.; L.F.P. Araújo; R.B. Gomes; M.F.R. Rosa; W. Paulino; L.F.S. Morais. 2005. Impactos ambientais do lançamento de efluentes da 
carcinicultura em águas interiores. Artigo Técnico. Eng. Sanit. Ambient, 10(2): 167-174.

Forster, I.P.; W. Dominy; L. Obaldo; A.G.J. Tacon. 2003. Rendered meat and bone meals as ingredients of diets for shrimp Litopenaeus vannamei (Boone, 1931). Aquaculture, 219: 655-670.

Garcia-Carreño, F.L. 1992. The digestive proteases of langostilla (Pleuroncodes planipes, Decapoda): their partial characterization and the effect of feed on their composition. Comp. Biochem. Physiol. 103B: 575-578.

García-Carreño, F.L.; M.A.N. Toro; P. Hernández-Cortés; J.M. Ezquerra; E. Serviere; A. Maeda. 1996. Tecnologia enzimatica en acuicultura. In: Avances en Nutrición Acuícola III. Cruz Suárez, L. E.; D. Ricque Marie; R. Mendoza (Eds.). Memorias 3er. Simposium Internacional de Nutrición Acuícola, Monterrey, Nuevo León, México. pp.251-265.

García-Carreño, F.L.; A.N. Toro; M. Equerra. 1997. Digestive shrimp proteases for evaluation of protein digestibility in vitro. I: Effect of protease inhibitors in protein ingredients. J.Mar. Biotechnol., 5:36-40.

Grabner, M. 1985. An in vitro method for measuring protein digestibility of fish feed components. Aquaculture, 48: 97-110.

Guillaume, J. 1997. Protein and amino acids. In: Crustacean Nutrition. D’Abramo, L.R; D.E. Conklin; D.M. Akiyama (Eds.). The World Aquaculture Society, Baton Rouge, LA,USA. pp. 26-50.

Guzmán, F.D. 1996. Principales ingredientes a utilizar en dietas para acuacultura. In: Fundamentos de nutrición y alimentación en acuicultura. Jaramillo, M.P.S., Gómez, H.R., Caza, P.V. (Eds.). Serie Fundamentos No 3, INPA (Instituto Nacional de Pesca Y Acuicultura), Colombia. pp 181-236. 
Hardy, R.W.; D.M. Gatlin. 2002. Nutritional strategies to reduce nutrient losses in intensive aquaculture. In: Cruz-Suárez, L.E.; D. Ricque-Marie; M. TapiaSalazar; M.G. Gaxiola-Cortés; N. Simoes (Eds.). Avances en Nutrición Acuícola VI. Memorias del VI Simposium Internacional de Nutrición Acuícola. Cancún, Quintana Roo, México.

IBAMA, 2005. Estatística da Pesca - Ano de 2004. Instituto Brasileiro do Meio Ambiente e dos Recursos Naturais Renováveis, Ministério do Meio Ambiente, Brasília, DF (boletim). 136 pp.

Iwai, M. 1978. Desenvolvimento larval e pós-larval de Penaeus (melicertus) paulensis Pérez-Farfante, 1967 (Crustacea, Decapoda) e o ciclo de vida dos camarões do gênero Penaeus da região centro-sul do Brasil. Tese de Doutorado. Universidade de São Paulo, Brasil. 137 pp.

Jackson, C.J.; N. Preston; M. Burford; P.J. Thompson. 2003. Managing the development of sustainable shrimp farming in Australia: the role of sedimentation ponds in treatment of farm discharge water. Aquaculture, 226: 23-34.

Kureshy, N.; D.A. Davis. 2002. Protein requirement for maintenance and maximum weight gain for the Pacific white shrimp, Litopenaeus vannamei. Aquaculture 204: $125-143$

Le Vay, L.; D.A. Jones; A.C. Puello-Cruz; R.S. Sangha; C. Ngamphongsai. 2001. Digestion in relation to feeding strategies exhibited by crustacean larvae. Comparative Biochemistry and Physiology. Part A, 128:623-630.

Leavitt, D. 1985. An evaluation of gravimetric and inert marker techniques to measure digestibility in the american lobster. Aquaculture, 47: 131-142.

Lee, P.G.; A.L. Lawrence. 1997. Digestibility. In: Crustacean Nutrition. D’Abramo, 
L.R; D.E. Conklin; D.M. Akiyama (Eds.). The World Aquaculture Society, Baton Rouge, LA, USA. pp. 194-260.

Lee, P.G., S.P. Meyers. 1997. Chemoattraction and feeding stimulation. In: Crustacean Nutrition. D’Abramo, L.R; D.E. Conklin; D.M. Akiyama (Eds.). The World Aquaculture Society, Baton Rouge, LA, USA. pp. 292-352.

Lemos, D. 2000. Metabolismo, composição bioquímica, conteúdo energético e atividade de proteinases digetivas durante o desenvolvimento larval e início do pós-larval do camarão Farfantepenaeus paulensis Pérez-Farfante, 1967 (Crustacea, Decapoda, Penaeidade), em cultivo. Tese de doutorado. Universidade de São Paulo, Brasil. 156pp.

Lemos, D.; J.M. Ezquerra; F.L. García-Carreño. 2000. Protein digestion in penaeid shrimp: digestive proteinases, proteinase inhibitors and digestibility. Aquaculture, 186: 89-105.

Lemos, D. 2003. Testing quality of feeds and feed ingredients: in vitro determination of protein digestibility with enzymes from the target species. International Aqua Feed. November/December. pp 40-42.

Lemos, D., B. Netto, A. Germano. 2003. Energy budget for juveniles of the subtropical shrimp Farfantepenaeus paulensis. World Aquaculture 2003, May 19-23 Salvador (Brazil). Book of Abstracts, p. 412.

Lemos, D.; A. Navarrete del Toro; J.H. Córdova-Murueta; F.L. Garcia-Carreño. 2004. Testing feeds and feed ingredients for juvenile pink shrimp Farfantepenaeus paulensis: in vitro determination of protein digestibility and proteinase inhibition. Aquaculture, 239: 307-321.

Lemos, D.; L. Samaritano; A.J.P. Nunes. 2006. Perspectives on the application of the $\mathrm{pH}$-stat in vitro protein digestibility routine with shrimp hepatopancreas 
enzymes to predict feed performance of Litopenaeus vannamei in a clear water culture experiment. Aqua 2006, May 9-13 Florença (Itália). Trabalho aceito para apresentação oral (contato: dellemos@usp.br).

Longas, M.P.D. 1996. Formulación de dietas. In: Fundamentos de nutrición y alimentación en acuicultura. Jaramillo, M.P.S., H.R.Gómez; P.V. Caza (Eds.). Serie Fundamentos, No 3, INPA (Instituto Nacional de Pesca Y Acuicultura), Colombia. pp. 237-272.

Nates, S; A. Tacon. 2005. Feed quality testing: measuring in vivo, in vitro digestibility. Global Aquaculture Advocate, 8(6): 44-45.

Obaldo, L.G.; S. Divakaran; A.G. Tacon. 2002. Method for determinating the physical stability of shrimp feeds in water. Aquaculture Research, 33:369-377.

Pedersen, B., B.O. Egum. 1983. Prediction of protein digestibility by an in vitro enzymatic pH-stat procedure. Tierphysiol. Tieternahrg u Futtermittelkde. 49:277-286.

Pedroza-Islas, R.; P. Gallardo; E.J. Vernon-Carter; T. García-Galano, C. Rosas; C. Pascual; G. Gaxiola. 2004. Growth, survival, quality and digestive enzyme activities of larval shrimp fed microencapsulated, mixed and live diets. Aquaculture Nutrition, 10: 167-173.

Seiffert, W.Q.; L.C. Marques; M.R. Borba; S.Z Gomes,. 1997. Estudo da eficiência de três rações comerciais e uma experimental sobre o crescimento de juvenis do camarão "rosa" Penaeus paulensis (Pérez Farfante, 1967) em condições de laboratório. B. Inst. Pesca. 24: 213-219.

Shiau, S. 1998. Nutrient requirements of penaeid shrimps. Aquaculture, 164: 77-93.

Shipton, T.A.; P.J. Britz. 2002. Evaluation of an in vitro digestibility technique for the prediction of protein digestibility in the South African abalone, Haliotis midae 
L. Aquaculture Nutrition, 8: 15-21.

Smith, D.M; S.J. Tabrett. 2004. Accurate measurement of in vivo digestibility of shrimp feeds. Aquaculture, 232: 563-580.

Smith, L.L.; P.G. Lee; A.L. Lawrence; K. Strawn. 1985. Growth and digestibility by three sizes of Penaeus vannamei Boone: effects of dietary protein level and protein source. Aquaculture, 46: 85-96.

Sudaryono, A.; E. Tsvetnenko; L.H. Evans. 1996. Digestibility studies on fisheries byproduct based diets for Penaeus monodon. Aquaculture, 143: 331-340.

Tacon, A.G.J. 2002. Thematic Review of Feeds and Feed Management Practices in Shrimp Aquaculture. Report prepared under the World Bank, NACA, WWF and FAO Consortium Program on Shrimp Farming and the Environment. Work in Progress for Public Discussion. Published by the Consortium. 69 pp.

Tacon, A.G.J.; I.P. Forster. 2003. Aquafeeds and the environment: policy implications. Aquaculture, 226: 181-189.

Tan, R.K.H.; W.G. Dominy. 1997. Comercial pelleting of crustacean feeds. In: Crustacean Nutrition. D’Abramo, L.R; D.E. Conklin; D.M. Akiyama. (Eds.). The World Aquaculture Society, Baton Rouge, LA, USA. pp. 520-549.

Valentini, H.; F. D’Incao; L.F. Rodrigues; J.E. Rebelo Neto; E. Rahn. 1991. Análise da pesca do camarão-rosa (Penaeus brasiliensis e Penaeus paulensis) nas regiões sudeste e sul do Brasil. Atlântica, Rio Grande. 13(1):143-157.

Valentini, H., F. D’Incao; L.F. Rodrigues. 2001. Evolução da pescaria industrial de camarão-rosa, Farfantepenaeus paulensis e F. brasiliensis, na costa sudeste e sul do Brasil. Notas Téc. Facimar, 5: 35-58.

Venou, B.; M.N. Alexis; E. Fountoulaki; I. Nengas, M.Apostolopoulou; I. CastritsiCathariou. 2003. Effect of extrusion of wheat and corn on gilthead sea bream 
(Sparus aurata) growth, nutrient utilization efficiency, rates of gastric evacuation and digestive enzyme activities. Aquaculture, 225: 207-223.

Waldige, V.; A. Caseiro. 2003. A indústria de rações: A situação atual e as perspectivas. Panorama da Aqüicultura. Março/Abril. pp. 37-45.

Watanabe, T. 2002. Strategies for further developmente of aquatic feeds. Fisheries Science, 68: 242-252. 